\title{
Analysis of Potential Self-Guarantee Tests for Demonstrating Financial Assurance by Non-Profit Colleges, Universities, and Hospitals and by Business Firms That Do Not Issue Bonds
}

Manuscript Completed: March 1997

Date Published: June 1997

Prepared by

P. Bailey, C. Dean, J. Collier, V. Dasappa, W. Goldberg

\section{DISCLAIMER}

ICF, Inc.

9300 Lee Highway

Fairfax, VA 22031-1207

C. Prichard, NRC Project Manager
This report was prepared as an account of work sponsored by an agency of the United States Government. Neither the United States Government nor any agency thereof, nor any of their employees, makes any warranty, express or implied, or assumes any legal liability or responsibility for the accuracy, completeness, or usefulness of any information, apparatus, product, or process disclosed, or represents that its use would not infringe privately owned rights. Reference herein to any specific commercial product, process, or service by trade name, trademark, manufacturer, or otherwise does not necessarily constitute or imply its endorsement, recommendation, or favoring by the United States Government or any agency thereof. The views and opinions of authors expressed herein do not necessarily state or reflect those of the United States Government or any agency thereof.
Prepared for

Division of Regulatory Applications

Office of Nuclear Regulatory Research

U.S. Nuclear Regulatory Commission

Washington, DC 20555-0001

NRC Job Code W6295
MASTER

HH 


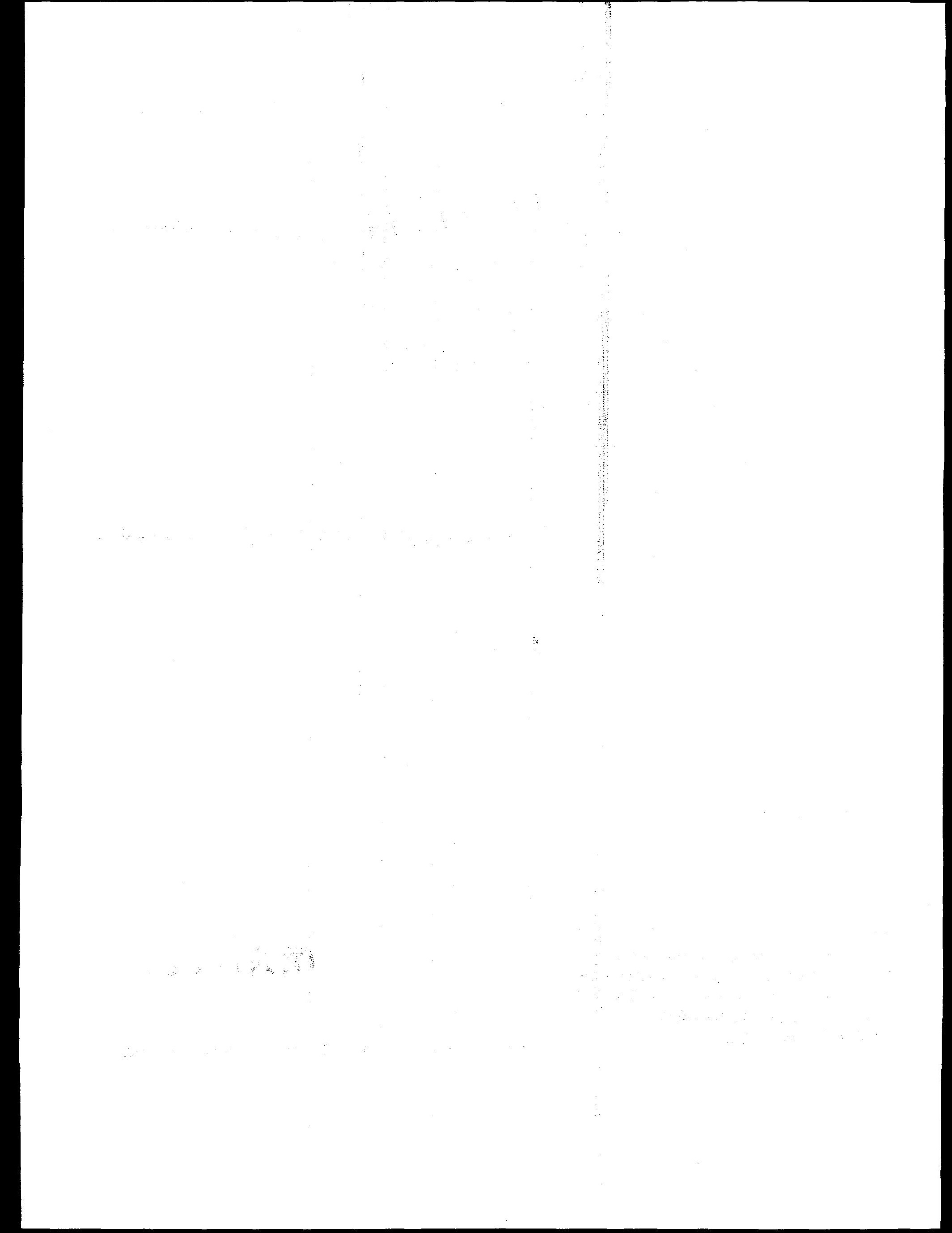




\section{DISCLADMER}

Portions of this document may be illegible in electronic image products. Images are produced from the best available original document. 


\section{ABSTRACT}

The Nuclear Regulatory Commission (NRC) on December 29, 1993, promulgated selfguarantee requirements that materials licensees may use to demonstrate financial assurance for decommissioning costs. However, nonprofit colleges and universities, nonprofit hospitals, and forprofit firms that do not issue bonds are currently precluded, by their unique accounting and financial reporting systems, or by other features of their business practices, from using the financial tests for self-guarantors adopted by the NRC. This Report evaluates several alternative financial tests that might serve as the basis for self-guarantee by these three categories of licensees.

For colleges and universities, tests for self-guarantee could include a bond rating requirement, as well as a size requirement (with size measured by current funds expenditures) or an assets requirement (with assets measured by endowment). A bond rating requirement of $\mathrm{A}$ or better from major ratings organizations would parallel the current NRC corporate self-guarantee requirements. Size or assets requirements could be based on several factors, including requirements that endowment (or alternatively an "unrestricted" subcategory of endowment) be at least a specified size; annual limits on expenditures from their endowments by colleges and universities; expected annual earnings from endowment; or estimates of how extensively colleges and universities could reallocate their current expenditures to address new obligations. A number of potential self-guarantee test criteria were evaluated by assessing the number of NRC college and university licensees that could pass each alternative. Out of 64 licensees, the most stringent alternative passed 16 schools ( 25 percent) and the least stringent passed 48 schools (75 percent).

For hospitals, tests for self-guarantee also could include a bond rating of $\mathrm{A}$ or better, as well as a financial characteristics requirement or a size requirement (with size measured as operating revenue). The three financial characteristics scores tested were liquidity, net revenues ("profitability"), and leverage, as reported in Profiles of U.S. Hospitals, an annual summary of financial information on hospitals published by HCIA Incorporated. The financial size characteristic required hospitals to have operating revenues of at least a certain amount relative to their assured decommissioning costs, on the basis that they could reallocate a portion of their operating revenue to pay for decommissioning. A number of potential self-guarantee test criteria were evaluated by assessing the number of NRC hospital licensees that could pass each alternative. Out of 26 licensees, the most stringent alternative passed 1-4 hospitals and the least stringent passed 13-14 hospitals.

For firms that do not issue bonds, tests for self-guarantee can be based on key financial ratios that are especially effective in identifying firms that may suffer financial problems in the future. The two ratios used were cash flow divided by total liabilities and total liabilities divided by net worth. A range of values for these ratios, varying in stringency, were tested. Out of 36 licensees, the most stringent alternative passed 2 firms and the least stringent passed more than 25 firms ( 69 percent). 


\section{CONTENTS}

1. INTRODUCTION

2. ANALYSIS OF POTENTIAL SELF-GUARANTEE TESTS FOR DEMONSTRATING FINANCIAL ASSURANCE BY COLLEGES AND UNIVERSITIES

2.1 SUMMARY OF POSSIBLE TEST DESIGN

2.2 CURRENT TRENDS AFFECTING FINANCIAL SITUATION OF COLLEGES AND UNIVERSITIES

2.3 EXISTING FINANCIAL RATIO TESTS FOR ASSESSING THE FINANCIAL CONDITION OF COLLEGES AND UNIVERSITIES $\ldots \ldots \ldots \ldots \ldots \ldots \ldots . \ldots$.

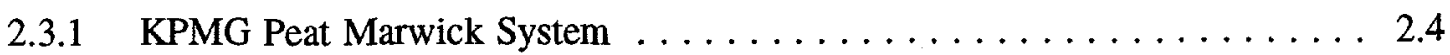

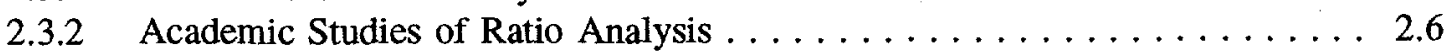

2.3.3 Financial Ratios Used by Bond Rating Firms $\ldots \ldots \ldots \ldots \ldots \ldots$

2.4 IMPACT OF NEW FINANCIAL ACCOUNTING STANDARDS

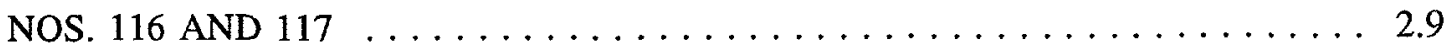

2.4.1 Financial Accounting Standards No. $116 \ldots \ldots \ldots \ldots \ldots \ldots \ldots . \ldots \ldots$

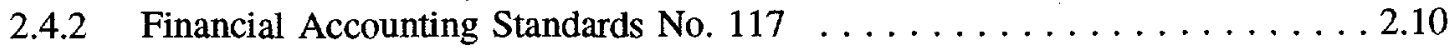

2.5 ALTERNATIVES TO RATIO-BASED SELF-GUARANTEE TESTS FOR COLLEGES AND UNIVERSITIES $\ldots \ldots \ldots \ldots \ldots \ldots \ldots \ldots \ldots \ldots \ldots \ldots \ldots \ldots \ldots .12$

2.5.1 College and University Endowment as a Test Criterion $\ldots \ldots \ldots \ldots \ldots 2.12$

2.5 .2 Bond Ratings as a Test Criterion . . . . . . . . . . . . . . . 2.15

2.5.3 Current Funds Expenditures as a Test Criterion . . . . . . . . . . 2.17

2.6 DATA ON COLLEGES AND UNIVERSITIES THAT ARE NRC MATERIALS

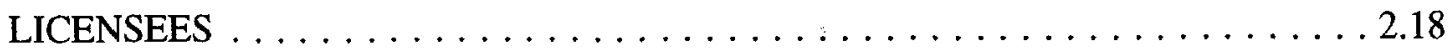

2.7 EVALUATION OF ALTERNATIVE THRESHOLDS $\ldots \ldots \ldots \ldots \ldots \ldots .23$

2.7.1 Alternative One: Bond Rating Criterion Plus Current Funds Expenditures

Requirement . . . . . . . . . . . . . . . . . . . 2.24

2.7.2 Alternative Two: Bond Rating Plus Endowment Requirement . . . . . . . 2.24

2.7.3 Alternative Three: Endowment Criterion and Current Funds Expenditure Requirement . . . . . . . . . . . . . . . . . 2.25

2.7.4 Alternative Four: Bond Rating or Unrestricted Endowment Requirement . . . 2.26

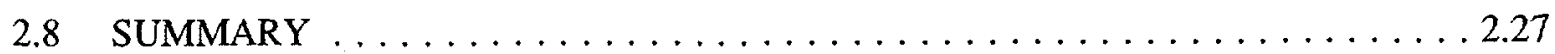


CONTENTS (continued)

Page

3. ANALYSIS OF POTENTIAL SELF-GUARANTEE TESTS FOR DEMONSTRATING FINANCIAL ASSURANCE BY HOSPITALS $\ldots \ldots \ldots \ldots \ldots \ldots \ldots \ldots \ldots \ldots .1$

3.1 SUMMARY OF POSSIBLE TEST DESIGN $\ldots \ldots \ldots \ldots \ldots \ldots \ldots \ldots \ldots .1$

3.2 BOND RATING CRITERION $\ldots \ldots \ldots \ldots \ldots \ldots \ldots \ldots \ldots \ldots \ldots \ldots \ldots \ldots \ldots \ldots$

3.3 POTENTIAL CRITERIA FOR NON-BOND RATING ALTERNATIVE $\ldots \ldots \ldots . .4 .4$

3.4 POTENTIAL CRITERIA FOR BOTH BOND RATING NON-BOND RATING

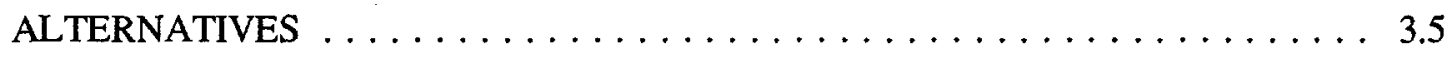

3.5 DATA ON HOSPITALS THAT ARE NRC MATERIALS LICENSEES $\ldots \ldots \ldots 3.8$

3.6 EVALUATION OF ALTERNATIVE THRESHOLDS $\ldots \ldots \ldots \ldots \ldots \ldots . .8$

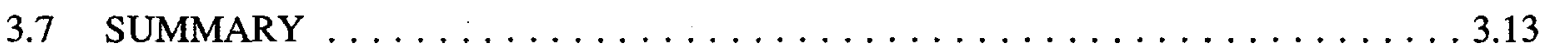

4. ANALYSIS OF ALTERNATIVE FINANCIAL ASSURANCE CRITERIA FOR SELF-GUARANTEE BY FIRMS THAT DO NOT ISSUE BONDS $\ldots \ldots \ldots \ldots \ldots 4.1$

4.1 KEY FINDINGS FROM PREVIOUS ANALYSIS OF ASSURANCE RISK $\ldots \ldots 4.2$

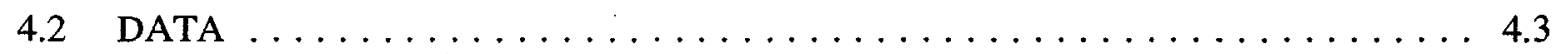

4.3 METHODOLOGY USED IN ANALYSIS OF SELF-GUARANTEE FINANCIAL TESTS . . . . . . . . . . . . . . . . . . . . . . . . 4.5

$4.4 \quad$ ANALYTICAL FINDINGS $\ldots \ldots \ldots \ldots \ldots \ldots \ldots \ldots \ldots \ldots \ldots .6 \ldots \ldots \ldots$

4.4.1 Analysis of Test One: $(\mathrm{CF} / \mathrm{TL})>0.07$ and $(\mathrm{TL} / \mathrm{NW})<2.7 \ldots \ldots \ldots \ldots .6$

4.4.2 Analysis of Test Two: $(\mathrm{CF} / \mathrm{TL})>0.1$ or $(\mathrm{TL} / \mathrm{NW})<1.5 \ldots \ldots \ldots \ldots .7$

4.4.3 Analysis of Test Three: $(\mathrm{CF} / \mathrm{TL})>0.1$ and $(\mathrm{TL} / \mathrm{NW})<1.5 \ldots \ldots \ldots \ldots .8$

4.4.4 Analysis of Test Four: $(\mathrm{CF} / \mathrm{TL})>0.15$ and $(\mathrm{TL} / \mathrm{NW})<1.5 \ldots \ldots \ldots . . \ldots$

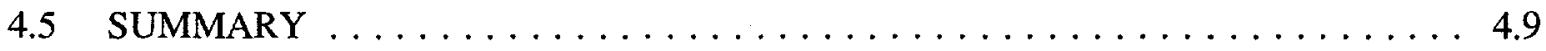

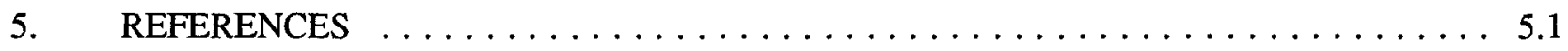




\section{TABLE OF EXHIBITS}

$\underline{\text { Page }}$

2-1 Summary of KPMG Peat Marwick Ratio-Based System for Financial Assessment of

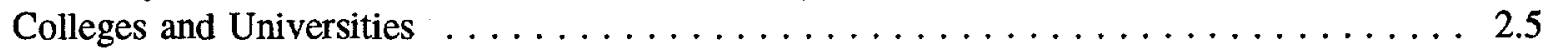

2-2 Summary of Key Financial Ratios $\ldots \ldots \ldots \ldots \ldots \ldots \ldots \ldots \ldots \ldots \ldots$

2-3 Factors Evaluated by Bond Rating Companies $\ldots \ldots \ldots \ldots \ldots \ldots \ldots$

2-4.a NRC College and University Materials Licensees (Public) $\ldots \ldots \ldots \ldots \ldots \ldots$

2-4.b NRC College and University Research Reactor Licensees (Public) $\ldots \ldots \ldots \ldots \ldots .21$

2-5.a NRC College and University Materials Licensees (Private) $\ldots \ldots \ldots \ldots \ldots \ldots .22$

2-5.b NRC College and University Research Reactor Licensees (Private) $\ldots \ldots \ldots \ldots .23$

2-6 Numbers of NRC College and University Licensees With A or Better Bond Rating and Current Funds Expenditures (CFE) Exceeding Alternative Thresholds . . . . . . . . . 2.24

2-7 Numbers of NRC College and University Licensees With A or Better Bond Rating and

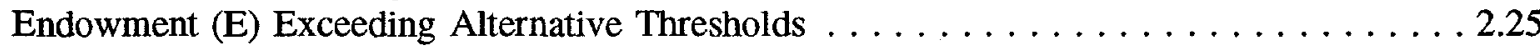

2-8 Numbers of NRC College and University Licensees With Endowment (E) and Current Funds Expenditures (CFE) Exceeding Alternative Thresholds $\ldots \ldots \ldots \ldots \ldots \ldots \ldots$

2-9 Numbers of NRC College and University Licensees With A or Better Rating or Unrestricted Endowment (UE) Exceeding $\$ 50$ Million $\ldots \ldots \ldots \ldots \ldots \ldots \ldots$

2-10 Comparison of Alternative Self-Guarantee Tests for Colleges and Universities $\ldots \ldots \ldots 2.27$

3-1 Financial Profile of NRC Nonprofit Hospital Materials Licensees . . . . . . . . . . . 3.9

3-2 Number and Percent of NRC Nonprofit Hospital Licensees Able to Pass the Financial

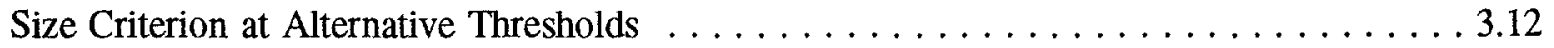

3-3 Number and Percent of NRC Nonprofit Hospital Licensees Able to Pass the Bond Rating Alternative and Non-Bond Rating Alternative, Assuming a One Percent Threshold for the Financial Size Criterion . . . . . . . . . . . . . . . . . . . . . . . 3.12

3-4 Number and Percent of NRC Nonprofit Hospital Licensees Able to Pass the Bond Rating Alternative and Non-Bond Rating Alternative, Assuming a One-Half of One Percent Threshold for the Financial Size Criterion 


\section{TABLE OF EXHIBITS (continued)}

3-5 Number and Percent of NRC Nonprofit Hospital Licensees Able to Pass the Bond Rating Alternative and Non-Bond Rating Alternative, Assuming a One-Tenth of One Percent Threshold for the Financial Size Criterion $\ldots \ldots \ldots \ldots \ldots \ldots \ldots \ldots \ldots \ldots \ldots \ldots$

3-6 Comparison of Alternative Self-Guarantee Tests for Hospitals . . . . . . . . . . . . 3.14

4-1 Estimated Baseline Annual Firm Failure Rates $\ldots \ldots \ldots \ldots \ldots \ldots \ldots \ldots \ldots$

4-2 Financial Test Alternatives for Self-Guarantee $\ldots \ldots \ldots \ldots \ldots \ldots \ldots \ldots$

4-3 Assurance Risk for Self-Guarantee Requiring $(\mathrm{CF} / \mathrm{TL})>0.1$ or $(\mathrm{TL} / \mathrm{NW})<1.5 \ldots \ldots .8$

4-4 Assurance Risk for Self-Guarantee Requiring (CF/TL) $>0.1$ and (TL/NW) $<1.5 \ldots \ldots .8$

4-5 Assurance Risk for Self-Guarantee Requiring (CF/TL) $>0.15$ and (TL/NW) $<1.5 \ldots \ldots .9$

4-6 Estimated Availability of Self-Guarantee Alternatives to NRC Materials Licensees That Do Not Issue Bonds 


\section{INTRODUCTION}

This report describes the analysis conducted to evaluate potential self-guarantee requirements that might be appropriate for use by nonprofit colleges and universities, nonprofit hospitals, ${ }^{1}$ or forprofit business firms that do not issue bonds. Each of these types of organization is currently precluded, by unique accounting and financial reporting systems, or by other features of its business practices, from using the financial test for self-guarantors adopted by NRC on December 29, 1993 (58 FR 68726). ${ }^{2}$

1 This analysis does not distinguish between "nonprofit" and "not-for-profit" entities. The Financial Accounting Standards Board (FASB) defines a not-for-profit organization as "an entity that possesses the following characteristics that distinguish it from a business enterprise: (a) contributions of significant amounts of resources from resource providers who do not expect commensurate or proportionate pecuniary return, (b) operating expenses other than to provide goods or services at a profit, and (c) absence of ownership interests like those of business enterprises. Not-for-profit organizations have those characteristics in varying degrees. . . . Organizations that clearly fall outside this definition include all investor-owned enterprises and entities that provide dividends, lower costs, or other economic benefits directly and proportionately to their owners, members, or participants. ..." NRC has generally used the term "nonprofit" to identify such entities. See, for example, "Restoration of the Generic Exemption from Annual Fees for Nonprofit Educational Institutions," 59 FR 12539 (March 17, 1994).

${ }^{2}$ NRC's financial test for self-guarantors requires a company to meet all of the following criteria:

(1) Tangible net worth at least 10 times the total current decommissioning cost estimate (or the current amount required if certification is used) for all decommissioning activities for which the company is responsible as self-guaranteeing licensee and as parent-guarantor.

(2) Assets located in the United States amounting to at least 90 percent of total assets or at least 10 times the total current decommissioning cost estimate (or the current amount required if certification is used) for all decommissioning activities for which the company is responsible as selfguaranteeing licensee and as parent-guarantor.

(3) A current rating for its most recent bond issuance of AAA, $\mathrm{AA}$, or A as issued by Standard and Poors (S\&P), or Aaa, Aa, or A as issued by Moodys.

A company must also satisfy the following criteria:

(1) The company must have at least one class of equity securities registered under the Securities Exchange Act of 1934.

(2) The company's independent certified public accountant must have compared the data used by the company in the financial test which is derived from the independently audited, yearend financial statements for the latest fiscal year, with the amounts in such financial statement. In connection with that procedure, the licensee shall inform NRC within 90 days of any matters coming to the attention of the auditor that cause the auditor to believe that the data specified in the financial test should be adjusted and that the company no longer passes the test.

(continued...) 
Each of these three categories is addressed in this report in the following sections:

- Section 2 discusses potential self-guarantee tests for colleges and universities. It describes ratio-based systems for assessing the financial condition of colleges and universities, and explains why these ratio-based systems are probably not a useful foundation for a self-guarantee test. Section 2 then describes criteria -- endowment funds and bond ratings -- for a self-guarantee test.

- $\quad$ Section 3 discusses potential self-guarantee tests for hospitals. It describes possible self-guarantee test alternatives, and then outlines bond rating and nonbond rating alternatives in detail.

- Section 4 discusses alternative financial assurance criteria for self-guarantees by business firms that do not issue bonds. It describes the method used to compare financial test criteria with the financial characteristics of licensees that do not issue bonds, and outlines financial criteria for a self-guarantee test for firms that do not issue bonds.

The self-guarantee criteria examined in this analysis reflect the following assumptions regarding NRC's goals for the self-guarantee tests:

(1) Level of Stringency. The test should pass only those licensees that are financially strong. This approach is financially conservative, and is also most analogous to NRC's approach in its corporate self-guarantee rule.

(2) Misprediction Error. The test should avoid passing licensees who later cannot fund decommissioning. It is unlikely that any self-guarantee test will be able to classify nonprofit institutions with 100 percent accuracy. Some colleges and universities and hospitals may pass the test but later prove unable to fund their decommissioning costs (Type 1 error). Other institutions may fail the test even though they will later be able to fund decommissioning (Type 2 error). The self-guarantee test should, insofar as possible, minimize Type 1 error, even if this goal does not minimize Type 2 error. This approach is most financially conservative. It is also consistent with the preceding assumption regarding the test's level of stringency.

(3) Incorporation of Commercial Ratings. The test can make use of informed third party judgments. NRC has previously incorporated bond ratings from Standard \& Poor's (S\&P) and Moody's into its corporate self-guarantee test and its parent company guarantee test. Incorporating bond ratings, as well as other (i.e., not bond related) rankings and ratings from commercial sources other than S\&P and Moody's, if the rankings and ratings are technically suited to the task at hand, can provide a well-tested method of assessment of financial

\footnotetext{
${ }^{2}(\ldots$ continued $)$
}

(3) After the initial financial test, the company must repeat passage of the test within 90 days after the close of each succeeding fiscal year. 
condition. The sources used must possess independence, scope, accuracy, and widespread public or commercial acceptance. Incorporating a commercial rating into a test for nonprofits is an efficient approach to test design, and can be expected to simplify the test considerably (e.g., if the rating can completely substitute for the use of financial ratios). 


\section{ANALYSIS OF POTENTIAL SELF-GUARANTEE TESTS FOR DEMONSTRATING FINANCIAL ASSURANCE BY COLLEGES AND UNIVERSITIES}

This section describes several alternatives for structuring a self-guarantee test for colleges and universities that are NRC materials licensees. In particular, it addresses alternatives that are feasible for use by both public and private nonprofit colleges and universities. ${ }^{1}$ This section is divided into seven subsections, as follows:

- Section 2.1 summarizes the provisions we believe would be appropriate to include in a self-guarantee test for colleges and universities.

- Section 2.2 discusses current trends affecting the financial situation of colleges and universities, with particular emphasis on trends that could impact NRC's ability to recover funds for decommissioning if necessary.

- Section 2.3 describes systems of financial analysis uncovered in our research that rely heavily or primarily on various financial ratios and that have been used in the past to evaluate the financial condition of colleges and universities, and indicates why we believe such ratio-based tests are currently not satisfactory for NRC's needs.

- Section 2.4 describes recent changes in the financial reporting requirements for colleges and universities, particularly Statements of Financial Accounting Standards (FAS) No. 116 and No. 117, and how these changes have affected the future use of the financial ratios described in Section 2.3.

- Section 2.5 describes criteria for a self-guarantee test, such as endowment and bond ratings, that do not rely directly on the submission of financial ratio data. This section provides the definitions of endowment and bond rating that are currently in common usage, and discusses the effect, if any, that FAS 116 and 117 are expected to have on these measures. It also introduces the concept of unrestricted endowment and its potential for use with the self guarantee.

- Section 2.6 provides a list of colleges and universities that are NRC materials licensees, along with the most recent available information concerning their endowments, endowments per full-time-equivalent student, bond ratings by S\&P and by Moody's, and current funds expenditures.

\footnotetext{
${ }^{1}$ NRC records indicate that several publicly owned and operated colleges and universities (so-called "state" schools) have sought to use statements of intent to demonstrate financial assurance for decommissioning. However, in the analysis described in this report, we indicate self-guarantee test criteria that may be suitable for both private and public colleges and universities, since NRC may wish to consider a test that could be used by publicly owned schools that cannot qualify for statements of intent.
} 
- Section 2.7 provides an assessment of the effect of alternative self-guarantee test criteria on the number of NRC college and university licensees that might be able to pass the tests at different levels of financial assurance.

- Section 2.8 provides a summary comparing the numbers of colleges and universities that may be capable of passing the test alternatives at different levels of stringency.

\subsection{SUMMARY OF POSSIBLE TEST DESIGN}

A self-guarantee test for colleges and universities could be structured to be parallel to NRC's existing test for corporate parent guarantors, which includes both a bond rating alternative and a nonbond rating alternative for those institutions that have not issued general obligation bonds. ${ }^{2}$ The two alternatives would differ with respect to certain criteria, but would share a number of common provisions.

\section{Bond Rating Alternative}

- $\quad$ Self-guarantor must have a current minimum bond rating (e.g., A or better as issued by Standard and Poor's or Moody's) on its most recent general obligation bond issuance. ${ }^{3}$

\section{Non-Bond Rating Alternative}

- $\quad$ Self-guarantor must rank above a certain level in size of endowment and/or "unrestricted" endowment as compiled in the National Association of College and University Business Officers (NACUBO) annual report on endowments.

- $\quad$ Self-guarantor must submit to NRC a letter from an independent certified public accountant which states that the accountant has compared the licensee's audited financial statements for the most recently completed fiscal year with the licensee's submission to NRC concerning endowment, and that the figures reported for endowment are identical to the figures found in the audited financial statements.

\section{$\underline{\text { Both Alternatives }}$}

- Self-guarantor must meet a minimum size requirement (e.g., minimum total net assets or minimum operating budget) expressed as a multiple of its decommissioning cost estimate or required certification amount for the most recently completed fiscal year.

\footnotetext{
${ }^{2}$ NRC's existing test for self-guarantors does not include a non-bond alternative. Among other alternative tests, this analysis evaluates self-guarantee tests for colleges and universities that do not issue bonds.

${ }^{3}$ This alternative could require that the bond issuance not have credit enhancement such as a bank letter of credit or bond insurance policy, or as discussed below in Section 2.5, ratings on insured bonds could be allowed.
} 


\section{Exhibit 2-1}

\section{Summary of KPMG Peat Marwick Ratio-Based System \\ for Financial Assessment of Colleges and Universities}

Questions One and Two: Is the reporting institution clearly financially healthy or not as of the reporting date? Is the reporting institution financially better off or not at the end than it was at the beginning of the year reported on?

Ratio 1: Expendable fund balances to plant debt

Ratio 2: Plant equity to plant debt

Ratio 3: Expendable fund balances to total expenditures and mandatory transfers

Ratio 4: Nonexpendable fund balances to total expenditures and mandatory transfers

Question Three: Did the reporting institution live within its means during the year being reported on?

Ratio 5: Net total revenues to total revenues

Ratio 6: Net educational and general revenues to total educational and general revenues

Ratio 7: Net auxiliary enterprise revenues to total auxiliary enterprise revenues

Question Four: Why have the institution's financial ratios behaved in the manner observed?

Ratios 8 through 13 describe contributions to revenue from different sources (i.e., tuition and fees; federal, state, and local govemment contributions; private gifts; and endowment) as percentages of total educational and general expenditures and mandatory transfers.

Ratios 14 through 21 describe categories of expenditures (i.e., instruction, research, public service, academic support, student services, institutional support, plant operation and maintenance, and scholarships and fellowships) as percentages of total educational and general revenues.

Questions Five and Six: Can the institution repay the indebtedness it is assuming? How should the degree of risk to investors and lenders be measured?

Ratio 22: Available assets to general liabilities

Ratio 23: Debt service to unrestricted current funds revenues

Ratio 24: Student matriculants to completed applications

Ratio 25: Opening fall FTE enrollment this year to opening fall FTE enrollment in base year 
Although the KPMG Peat Marwick ratio-analysis system is a well-designed and sophisticated method of evaluating the financial condition of colleges and universities, there are at least three reasons why it is not an adequate basis for the development of a self-guarantee test for NRC materials licensees:

Many of the ratios do not have specified thresholds (i.e., precise numerical values have not been identified for many of the ratios indicating what is "acceptable" or "unacceptable" performance on those ratios). Thresholds have been identified for only about a quarter of the ratios. The thresholds that are presented are not consistent or expressed in terms useful for a self-guarantee test because they are given in ranges. Several thresholds are used to reinforce or weaken judgments derived from other ratios. Furthermore, the thresholds that are presented are not fully consistent in their terms. In some cases, the thresholds indicate the boundaries of areas of concern. In other cases, the thresholds indicate the boundaries of areas of high confidence. Of the 25 ratios presented, only four or five both have thresholds and address financial characteristics highly pertinent to a self-guarantee test. Even for these ratios, the thresholds are not directed consistently at the same level of risk.

Reference data contained in the study are of limited use. KPMG Peat Marwick has tabulated results for each of the 25 ratios for the years following 1987 for groups of selected colleges and universities organized by ranges in the sizes of their operating budgets. Although these tables would provide some opportunity to test alternative cutoff points for a self-guarantee test, the results would be limited by two factors. First, although the NRC licensees encompass schools in a broad range of sizes, the majority would probably fall within only one or two of the KPMG Peat Marwick operating budget categories. The largest category, $\$ 100$ million in annual operating budget, includes only six schools for each of the four years. Some or all of the NRC licensees might be members of this group. Second, the KPMG Peat Marwick data are arrayed by quartiles, which would preclude finer distinctions.

\subsubsection{Academic Studies of Ratio Analysis}

A number of academic studies of ratio analysis of the financial condition of colleges and universities have been published. ${ }^{9}$ A summary study, which collects and evaluates much of the literature on college and university financial analysis and presents a set of recommended financial ratios to be used in analysis of the financial condition of nonprofit organizations, was published by

9 In addition to the study described in this section, a literature search uncovered the following: Dickmeyer, N., "Assessing the Financial Health of Institutions," Educational Record, 1979; Taylor, B., "Monitoring the Financial Condition of Colleges and Universities, AAHE Bulletin, 1984; Jenny, H. and J. Minter, "Updating Financial Ratios," NACUBO Business Officer, 1993, as well as a number of other studies from the late 1970's and early 1980's. Some of these studies also contain extensive lists of references to financial ratio analysis for nonprofits generally. Because of the impact of FAS 116 and 117, however, we have not undertaken an extensive review of all of these studies. 
Chabotar in $1989 .{ }^{10}$ It organizes the recommended ratios into five categories, summarized in Exhibit 2-2 according to the key financial topics that they illustrate:

In general, Chabotar provides thresholds for the ratios he recommends. In some cases, both Chabotar and KPMG Peat Marwick use the same ratio, and provide a threshold for that ratio. Those thresholds were generally consistent, but not in ways that would be helpful for the design of a

\section{Exhibit 2-2}

\section{Summary of Key Financial Ratios}

Liquidity -- Estimating capacity to maintain adequate cash flow to pay bills as accrued

Ratio 1: Current Ratio: Unrestricted current assets to unrestricted current liabilities

Ratio 2: Quick Ratio: Unrestricted current assets minus inventories to unrestricted current liabilities

Ratio 3: Available funds Ratio: Cash and short term investments to unrestricted current liabilities

Debt Structure

Ratio 4: Debt-equity Ratio: Plant debt to net investment in plant

Ratio 5: Debt-service Ratio: Debt service to operating revenue

Sources of Funds

Contribution Ratios (for each source of revenues): Sources of revenues to total expenditures

\section{Uses of Funds}

Expenditure Ratios (for each category of expenditures): Expenditures by program or function to total expenditures

Net Operating Results

Total revenues to expenditures: Annual operating surplus or deficit

self-guarantee test. For example, both agree that in the long term the ratio of revenues to expenditures should be positive, but for a self-guarantee test it could be more important to specify on a short-term (annual) basis a numerical threshold specifying the degree to which the ratio must be positive.

10 Kent John Chabotar, "Financial Ratio Analysis Comes to Nonprofits," 60 Journal of Higher Education, March/April 1989. 
The ratios that Chabotar proposes are quite generic. Calculation of these ratios also will be affected, like the KPMG Peat Marwick system, by FAS 116 and $117 .^{11}$ Providing operational definitions for these ratios therefore will be difficult until more details are available on how colleges and universities are responding in practice to FAS 116 and 117.

\subsubsection{Financial Ratios Used by Bond Rating Firms}

Bond rating companies use a variety of factors in their assessments. Among these factors are a number of financial ratios. The financial ratios used by Standard \& Poor's are presented in this section. S\&P relies on twelve ratios, summarized in Exhibit 2-3, pertinent to private institutions.

Although their terminology differs, bond rating firms apparently take into account several of the key factors that are addressed in the KPMG Peat Marwick and Chabotar ratio-analysis systems (and that tend to have thresholds provided for them), including the following:
- Liquidity
- Debt service burden
- Annual net operating results
- $\quad$ Expendable funds available
- Financial aid expended relative to tuition income received.

Thus, the analytic input provided by these ratios remains available, indirectly, through bond ratings for colleges and universities with rated debt. In addition, the use of these analytic ratios is not expected by Standard and Poor's to be substantially affected by changes in accounting and reporting standards pertaining to nonprofit colleges and universities brought about by FAS 116 and 117. S\&P anticipates that it will be able to secure all necessary information from institutions seeking ratings, and will ask them to provide additional data if necessary, to ensure S\&P can determine its ratings are consistent over the change. ${ }^{12}$ The most important of those accounting and reporting changes are discussed in the next section.

\footnotetext{
${ }^{11}$ Chabotar published his study before the release of FAS 116 and 117. He recognizes the need for ratio analysis to reflect the accounting system used by the objects of the analysis. For example, he points out that any ratio analysis "has to accommodate how nonprofits organize their financial resources in order to fulfill legal obligations and keep those resources available for particular purposes: (a) by fund and (b) by restricted versus unrestricted resources." (p. 190) He notes that the value of net investment in plant recognized on the institution's balance sheet may vary significantly depending on whether it is valued at cost or market value. Finally, he notes that nonprofits can "obscure their operating deficits by inter-fund borrowing or transfers, accrual of revenues from another accounting period, deferral of expenditures into another period, or the depletion of fund balances." He suggests that analysis of net operating results should be done separately for each fund and over a sufficient period of time to capture the effect of accruals and deferrals, and through the calculation of ratios both including and excluding mandatory transfers in net revenue. (p. 200)

12 Telephone contact between ICF staff and S\&P staff, October 3, 1994.
} 


\section{Exhibit 2-3}

\section{Factors Evaluated by Bond Rating Companies}

(1) Ratio of debt to endowment:

(2) Endowment liquidity ratio:

(3) Endowment per student:

(4) Endowment to operations ratio:

(5) Expected debt burden:

(6) Aid to tuition ratio:

(7) Gift income ratio:

(8) Historic debt burden ratio:

(9) Tuition dependence ratio:

(10) Unrestricted liquidity ratio:

(11) Unrestricted funds operations:

(12) Year-end unrestricted funds. balance:
Total long-term debt to total endowment

Restricted (quasi) endowment to total endowment

Total endowment/FTE students

Total endowment to unrestricted current fund expenditures and mandatory transfers

Expected maximum debt service to most recent unrestricted current fund expenditures and mandatory transfers

University-generated financial aid to tuition revenues

Unrestricted private gifts to total unrestricted educational and general revenues

Debt service to related year's unrestricted current fund expenditures and mandatory transfers

Unrestricted tuition revenues to total unrestricted educational and general revenues

Unrestricted cash and investments to accounts payable

Surplus or deficit as a percentage of unrestricted current fund expenditures and mandatory transfers

Unrestricted funds balance to unrestricted current fund expenditures and mandatory transfers

\subsection{IMPACT OF NEW FINANCIAL ACCOUNTING STANDARDS NOS. 116 AND 117}

In June 1993, the Financial Accounting Standards Board (FASB) issued two statements that establish new standards for the financial reporting of nonprofit organizations, including colleges and universities and hospitals. These statements are:

- Statement of Financial Accounting Standards No. 116, Accounting for Contributions Received and Contributions Made.

- Statement of Financial Accounting Standards No. 117, Financial Statements of Not-For-Profit Organizations. 
The full impact of these statements on accounting and reporting by nonprofit institutions has not yet been felt. ${ }^{13}$ Both statements are effective for fiscal years beginning after December 15 , 1994 , except for organizations with less than $\$ 5$ million in total assets and less than $\$ 1$ million in annual expenses. For those organizations, the statements are effective for fiscal years beginning after December 15, 1995.

The requirements and implications of each statement are described briefly below.

\subsubsection{Financial Accounting Standards No. 116}

FAS 116 establishes accounting standards for contributions received and contributions made by nonprofit organizations, with the objective of making reporting among nonprofits more uniform. At present, some nonprofits record certain unconditional promises to give as assets and revenue when the promises are made, while others record them as deferred revenue. Most colleges and universities record them only when the amounts promised are actually received. ${ }^{14}$

FAS 116 requires that contributions received and made by an organization are recognized as revenues at their fair values in the period in which they are received or made. In addition, unconditional promises to give should be recognized and recorded in the period in which such pledges are made. FAS 116 further requires nonprofit organizations to distinguish between contributions received that increase permanently restricted net assets, temporarily restricted net assets, and unrestricted net assets. Any subsequent interest earned on a contribution is contribution income and should be reported as an increase in one of the three net asset categories. Finally, expiration of donor restrictions should be recognized in the period in which the restrictions expire. ${ }^{15}$

The major implications of FAS 116 for colleges and universities appear to be (1) the requirement to recognize unconditional promises to give when the promises are made (before the amounts are received) and (2) the need to classify contributions into the three major net asset categories, in parallel with the requirements of FAS 117.

\subsubsection{Financial Accounting Standards No. 117}

FAS 117, popularly known as the "display" rule, establishes certain minimum, uniform standards for all nonprofit organizations to follow when preparing their financial statements. FAS 117 's objective is to make such financial statements more relevant, understandable, and comparable,

13 The literature suggests that the impact is likely to be greater on colleges and universities than on hospitals because colleges and universities have in the past used a number of different accounting and reporting standards and because, in particular, of the changes caused by FAS 116 in accounting for contributions received.

14 Brown, V.H. and S.E. Weiss, "Toward Better Not-For-Profit Accounting and Reporting," Management Accounting, July 1993.

15 Statement of Financial Accounting Standards No. 116, Accounting for Contributions Received and Contributions Made, Financial Accounting Standards Board. NACUBO has recently published guidance for college and university staff: John Ostrom, Accounting for Contributions: Understanding the Requirements of FASB Statement No 116, NACUBO, 1996. 
and provide information that focuses on the entity as a whole. ${ }^{16}$ At present, the financial statements of nonprofit entities tend to differ in their format and content. Further, colleges and universities prepare financial statements that report the financial position of individual fund groups and may not provide information for the entity as a whole. ${ }^{17}$

Under FAS 117, a complete set of financial statements for private colleges and universities will include the following:

- $\quad$ Statement of Financial Position (or Balance Sheet). FASB requires that the amounts for six basic elements be displayed on the balance sheet: total assets, total liabilities, unrestricted net assets, temporarily restricted net assets, permanently restricted net assets, and total net assets; ${ }^{18}$

- $\quad$ Statement of Activities. This statement is similar to income statements prepared by business enterprises, although the focus is on changes in net assets rather than net income;

- Statement of Cash Flow. This statement provides information on cash receipts, cash payments, and net increase (or decrease) in cash over the relevant period;

- $\quad$ Accompanying Notes. These notes accompany the financial statements and provide additional information on certain items in the statements.

FAS 117 allows a certain amount of flexibility in the precise format and presentation of financial statements. For example, within the broad asset and liability categories, a college or university may provide additional details by fund category. ${ }^{19}$

Overall, FAS 117 is expected to move private colleges and universities away from fund accounting and toward reporting standards used by corporations. This change has implications for financial ratios that have been used in the past as indicators of a college or university's financial strength. Financial statements of most colleges and universities may no longer contain detailed fund information on which several ratios tend to be based. For example, the balance sheet item "unrestricted current fund" may no longer exist. ${ }^{20}$ In addition, some new revenue and asset items may appear in the financial statements. ${ }^{21}$

16 Statement of Financial Accounting Standards No. 117, Financial Statements of Not-For-Profit Organizations, Financial Accounting Standards Board, June 1993.

17 Brown and Weiss, July 1993.

18 Net assets is equal to total assets minus total liabilities.

19 Harr, D.J. and R.H. Frank, "Coming: New Nonprofit Financial Statements (Part 1)," Nonprofit World, May/June 1994.

20 Standard \& Poor's Municipal Finance Criteria, 1994, p. 87.

21 Telephone conversation with Bob Gallo, Partner, Peat Marwick, September 1994. 


\subsection{ALTERNATIVES TO RATIO-BASED SELF-GUARANTEE TESTS FOR COLLEGES AND UNIVERSITIES}

A test for self-guarantee that is not ratio-based is likely to be simpler and more effective than a ratio-based test. In addition, such a self-guarantee test can be made to resemble more closely the self-guarantee test for corporations. The three major criteria that would most closely parallel the selfguarantee test for corporations, and that could be used effectively in a self-guarantee test for colleges and universities, are endowment, general operating expenditures, and bond rating. These criteria parallel the assets, tangible net worth, and bond rating criteria of the corporate self-guarantee test. Each is discussed in turn in this section.

\subsubsection{College and University Endowment as a Test Criterion}

In comments submitted to the NRC on March 22, 1993, in response to the proposed rule on self-guarantee for materials licensees, Carnegie Mellon University stated that it believed NRC should allow colleges and universities "with sufficient discretionary resources to self-guarantee." Carnegie Mellon went on to suggest that a measure, similar to tangible net worth but better adapted to colleges and universities, would be "market value of discretionary endowment at least 10 times the current total decommissioning cost." Massachusetts Institute of Technology and the University of Notre Dame, the only other colleges and universities to comment on the proposed rule, did not state that endowment should be substituted for tangible net worth, although Notre Dame did recommend that the tangible net worth requirement be placed at $\$ 500$ million, and MIT suggested that it be limited to ten times the decommissioning cost estimate.

In order for endowment to serve as a useful component of a self-guarantee test (1) a consistent definition for the term must be available and (2) a source must be available for verifying the size of

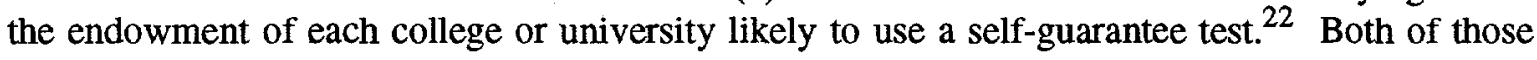
criteria are satisfied through work done by NACUBO.

NACUBO sponsors the preparation of an annual study of college and university endowment that provides annual information on the endowments of over 400 institutions. ${ }^{23}$ The NACUBO study uses a definition of endowment and related terms that can be adopted for use in a self-guarantee test:

Endowment -- Assets donated by individuals or organizations to provide permanent capital and an ongoing stream of current income for an institution. Includes one or

22 The self-guarantor would submit evidence to NRC that it meets all test requirements needed to pass the test. This evidence could include a certified statement concerning the size of its endowment.

23 The study covers approximately 300 private colleges and universities and about 130 public institutions. It indicates the market value of endowment assets, and calculates the endowment assets per FTE student. In addition, for each school, it shows the types of assets that make up the endowment. Information for the report is collected following the close of the schools' fiscal years (for almost all schools, June 30, with most others closing in May) and appears the following January. The study has been conducted for the past ten years. This report relies on 1993 NACUBO Endowment Study, prepared by Cambridge Associates, Inc., 1994; 1994 NACUBO Endowment Study, prepared by Cambridge Associates, Inc. 1995; and 1995 NACUBO Endowment Study, prepared by Cambridge Associates, Inc. 1996. 
more of the following components--true endowment, term endowment, and quasiendowment--and generally excludes life income and annuity funds. ${ }^{24}$

Endowment is one of the factors reviewed by bond-rating companies in evaluating the financial strength of an institution. According to S\&P:

Depending on their size and restrictions, endowment monies can give an institution significant financial strength and enhance liquidity. Growth trends in endowment are examined [in the bond rating analysis] and endowment-related investment and spending policies are analyzed. Endowment levels are compared with an institution's debt level and budget, and a per-student endowment level is calculated and compared with those of other colleges and universities. S\&P looks at the makeup of the endowment to determine what portion is unrestricted or quasi-endowment. Generally, S\&P prefers a high proportion of unrestricted endowment funds because it gives the greatest degree of flexibility. However, a sizable endowment, even when restricted, can provide significant strength as it produces spendable interest income. ${ }^{25}$

Three alternative methods were used to define potential threshold values for endowment, and "unrestricted" endowment, as a self-guarantee criteria. These thresholds then were used to estimate the number of colleges and universities that might be able to pass alternative self-guarantee tests. Because very few colleges and universities suffer financial failure, however, there is no sample of closed, merged, or bankrupt colleges and universities with which to test the likelihood of misprediction at alternative threshold values.

${ }^{24} 1993$ NACUBO Endowment Study, pp. 348-351, provides the pertinent definitions. Annuity Funds are defined as assets donated by individuals or organizations with the stipulation that the institution bind itself to pay stipulated amounts to donor or donor-designated beneficiaries. Payments terminate at a specified time. Life Income Funds are defined as assets donated by individuals or organizations on the condition that the institution bind itself to pay a specified level of income, expressed as a percentage of donated assets or as a dollar amount, to the donor or designated beneficiary for the lifetime of such beneficiaries. After the death of the beneficiaries, the institution gains complete ownership of the donated assets. Life income funds are generally not considered part of an endowment while income is paid to beneficiaries. Quasi-Endowment is defined as assets donated by individuals or organizations to an institution that the institution's governing board has decided to treat as permanent capital. Because this decision is optional, principal as well as income may be expended if the board so desires. Term Endowment is defined as assets donated by individuals or organizations to an institution with the understanding that all or part of the principal may be expended after a stated period of time or the occurrence of a particular event. The income earned is available for expenditure by the institution. True Endowment is defined as assets donated by individuals or organizations to an institution as permanent capital. Usually only income is spent, although in many cases applicable law provides for the expenditure each year of a defined portion of principal, if a governing board so authorizes.

${ }^{25}$ Standard and Poor's, S\&P's Municipal Fund Criteria, 1994, pp. 86-87. 
The three alternative methods for setting an endowment threshold were:

(1) Several "typical" values were estimated for the likely decommissioning costs for a college or university licensee. ${ }^{26}$ Using a conservative estimated rate of return on endowment assets, ${ }^{27}$ the threshold can be set at the size of the endowment necessary to yield income sufficient to fund an alternative form of financial assurance for decommissioning, or to fully fund a standby trust in the total amount of the decommissioning cost estimate, in one year, assuming that all endowment income goes to pay for decommissioning in that year.

(2) Endowment could be required to equal or exceed some multiple of decommissioning costs, as suggested by Carnegie Mellon University. Because colleges and universities generally are restricted in the proportion of their endowments that can be spent annually to approximately $5 \%$ of endowment market value, the threshold could be set at 20 times the cost estimate. ${ }^{28}$

(3) Colleges and universities could be required to demonstrate a specified level of "unrestricted endowment." Schools may be required to calculate this figure, from quasi endowment and certain categories of endowment earnings, but apparently such calculations are not difficult, since about 460 schools provide data for the annual NACUBO endowment study. Such a requirement would be stated in terms of the category of funds that NRC is chiefly interested in -funds that are available to the managers of the college or university to expend without restriction.

It should be noted, however, that even "unrestricted endowment" has two potential limitations.

- $\quad$ First, as of 1995 fiscal year-end, according to NACUBO, quasi endowment amounted to 31.8 percent of total endowment for public institutions (dollarweighted mean) and 31.7 percent for private institutions. Although the information necessary to calculate this statistic is apparently reported by institutions as part of NACUBO's endowment study, it is not included in the annual endowment study in a disaggregated form. Thus, as it currently is

\footnotetext{
${ }^{26}$ A sample of financial assurance submissions from colleges and universities was used to develop these cost estimates. For 23 schools (8 public and 15 private), decommissioning cost estimates ranged from $\$ 20,000$ to $\$ 12.5$ million. The mean cost for public schools was about $\$ 900,000$ and for private schools about $\$ 1.5$ million, with the mean for both categories combined about $\$ 1.3$ million.

27 According to NACUBO, for fiscal year 1994, college and university investment pools earned a mean total return of $2.9 \%$ (equal-weighted) to 4.4\% (dollars-weighted) (1994 NACUBO Endowment Study, Exhibit 25, p. 96). This rate of return, however, is substantially lower than the three-, five-, and 10-year average annual returns calculated by NACUBO. For this analysis, rates of return of $3 \%$ and $12 \%$ were used. The latter rate is slightly lower than the public and private equal-weighted mean rates of retum calculated by NACUBO $(12.3 \%$ and $12.6 \%$ respectively) and the median rate of return (12.7\%) for the ten-year period 1984-1994. A $12 \%$ rate of return slightly exceeds the rate calculated for the smallest ( $\$ 25$ million and under) college and university investment pools for the ten-year period.
}

${ }^{28}$ See 1994 NACUBO Endowment Study, Exhibit 9: Endowment Spending Rules Fiscal Year 1994, pages 47-77. 
prepared, the NACUBO study could not serve as a source for verification of information reported to NRC on unrestricted endowment by a specific college or university.

- Second, colleges and universities generally follow policies limiting the amount that they spend from endowment each year. In fiscal 1995, according to NACUBO's statistics for about 350 institutions, total withdrawals from endowment for public schools averaged 6.3 percent and for private schools 6.0 percent, with about 1.5 percent of those withdrawals corresponding to investment management and other expenditures and 4.7 percent corresponding to actual endowment payout. If an institution planning to cover a $\$ 1.5$ million decommissioning cost from unrestricted endowment also planned to retain a five percent expenditure cap, it would need at least $\$ 30$ million in unrestricted endowment. A $\$ 50$ million unrestricted endowment requirement, for example, would allow an institution to cover up to $\$ 2.5$ million in decommissioning costs and still maintain a five percent spending cap.

There are substantial differences in the levels of endowment between private and public colleges and universities. Therefore, potential thresholds were tested with both groups combined and kept separate for purposes of establishing an endowment threshold.

\subsubsection{Bond Ratings as a Test Criterion}

A bond rating is an opinion on the ability of the issuer to meet its repayment obligations in a timely manner. Ratings also provide a comparative framework within which the risk associated with different bonds of different issuers can be compared. Both of the best known bond rating agencies in the U.S., S\&P and Moody's, rate bonds issued by colleges and universities. These ratings are based on a detailed evaluation process, are widely accepted in the financial community, and are publicly available. These characteristics of bond ratings make them an attractive criteria to use in an NRC selfguarantee test.

S\&P and Moody's go through an extensive financial evaluation process and credit analysis before they assign ratings to the debt of an organization. The process generally includes a meeting with management, examination of financial statements, and research into industry and market conditions. In addition, rating agencies frequently obtain information that is not publicly available from the organization itself. ${ }^{29}$

29 S\&P's Municipal Finance Criteria, 1994 and Moody's Rating Process, 1989. Recent reports indicate that the ratings organizations are revising their criteria to reflect FASB 116 and 117, The Wall Street Journal, "Rating college debt calls for refresher course as standards change," May 25, 1995, A1. 

factors:

When assigning ratings to private college and university bonds, S\&P evaluates the following

- $\quad$ Demand. S\&P measures demand by evaluating enrollment size trends, admissions policy, ability to draw students from wide geographic areas, the quality of faculty and students, popularity of program offerings, competition, and the rate of attrition as measured by student dissatisfaction.

- Financial condition. In evaluating a college or university's financial strength, S\&P focuses on historical and projected trends in revenue, the extent of diversification of the revenue base, expenditures and an institution's ability to reduce costs, operating results, debt, and endowment size. As discussed earlier, S\&P evaluates several financial ratios. Therefore, the bond ratings reflect such financial ratio analysis.

- $\quad$ Management ability. S\&P evaluates a management's ability to foresee and plan for potential challenges, strategies and policies, track record, and management turnover.

- Legal provisions of the debt. S\&P examines the legal provisions of the debt, including security pledges applied to the debt, covenants governing the debt, reserve funds to service debt, and credit support (e.g., collateral).

Colleges and universities issue a variety of bonds, including general obligation bonds, bonds that are insured or backed by another entity, and bonds whose repayment is contingent based on revenue from a specific source (e.g., stadium revenue bonds). Of these, ratings on general obligation bonds are likely to be the most useful for NRC's purposes because they reflect the overall financial strength of the college or university.

Because NRC has already used A or better ratings in the current self-guarantee test as the threshold value, using that rating as the threshold criterion for colleges and universities would help maintain consistency across the Commission's self-guarantee tests.

A substantial number of colleges and universities have issued insured bonds. Approximately 40 percent of university debt is insured by a bond insurance company. Three bond insurance companies account for 90 percent of this insurance market. These companies are Municipal Bond Investors Assurance Corporation (MBIA), AMBAC Indemnity Corporation (AMBAC), and Financial Guaranty Insurance Company (FGIC). University debt comprises only a small percentage of these companies' insured portfolios.

Bond insurance provides a guarantee of payment of principal and interest in accordance with a bond issue's original payment schedule. Based on the insurance, bond rating agencies such as Moody's and Standard and Poor's automatically assign the insured bonds a rating (typically triple-A) identical to that of the insurance company providing the guarantee. Bond rating agencies do not directly consider the creditworthiness of the issuer when assigning ratings on insured bonds. 
The issuer's creditworthiness is, however, the focus of the bond insurer's underwriting process. Bond insurance companies evaluate the financial condition of the issuers they insure and avoid issuing policies to universities that are not creditworthy. Consequently, the presence of bond insurance (and the triple-A rating that accompanies it) indicates that the issuer is in sound financial condition. In fact, almost all insured university debt would receive an investment grade rating (i.e., Baa/BBB or higher) without insurance. Ratings on insured bonds do not fluctuate as the financial condition of the issuer changes. If an issuer's financial condition deteriorates, the rating on its insured bonds remains constant. Nevertheless, bond insurers monitor the financial condition of issuers for as long as insured bonds are outstanding. If this surveillance causes the insurer to believe that an issuer may be in jeopardy of defaulting on insured debt payments, the insurer may advise the issuer of ways to improve its financial condition and avoid default. ${ }^{30}$

To earn and retain a triple-A rating, the top bond insurance companies must undergo regular and stringent evaluations by the bond rating agencies. Factors considered in rating bond insurers include financial condition, underwriting methodology, current portfolio of bonds, and level of surveillance.

Information on insured bonds issued by colleges and universities that are NRC licensees was collected and tested as a self-guarantee criterion.

\subsubsection{Current Funds Expenditures as a Test Criterion}

A test criterion reflecting the overall financial size of the colleges or universities could be provided by either net total assets or current funds (general operations) expenditures.

Net total assets are required by FAS 117 to be reported by all colleges and universities following the financial accounting standards. As total assets minus liabilities, net total assets can be determined relatively easily from college and university balance sheets. (However, neither NACUBO or the National Center for Education Statistics could provide aggregate statistics or data by school on net total assets.) As a category, net total assets represents a close equivalent to the tangible net worth category used in the corporate parent guarantee financial test. Use of net total assets as a criterion would, however, mean that the size of the endowment of a college or university would play a very large role in determining whether it could pass the self-guarantee test, since endowment would be counted as a component of net total assets as well as considered independently.

As an alternative to net total assets, the size of a college or university's operating budget could also be used as an indicator of financial strength and stability. As in the case of endowment and assets, the larger and more prosperous colleges and universities are likely to have larger operating budgets. In addition, if operating budget is included as a criterion in a self-guarantee test it will be independent of the bond rating criterion because $S \& P$ does not take this variable into account when assigning their ratings. ${ }^{31}$ Large colleges and universities tend to have operating budgets of over $\$ 100$ million while very large colleges and universities generally have operating budgets greater than $\$ 700$ million or even one billion dollars.

${ }^{30}$ For certain bond issuances, the insurer may have the right to intervene in the management of the issuer.

31 An S\&P analyst, however, ratified our conjecture that colleges and universities with large operating budgets are probably more financially stable than those with small operating budgets. We do not have any information on whether Moody's takes operating budget into account when assigning their ratings. 
Because annual data are available from the Department of Education on revenues and expenditures of colleges and universities, current funds expenditures was used for this analysis. Data on current funds expenditures by the colleges and universities of interest were obtained from the Integrated Postsecondary Education Data System (IPEDS) surveys administered for the National Center for Education Statistics of the U.S. Department of Education. The most recent available IPEDS data files cover the period 1991-1992. In addition, IPEDS considers branch campuses as individual units. The amounts presented in Exhibits 2-4 and 2-5 were not adjusted to account for any increases in expenditures or for inflation between 1992 and 1994, nor were amounts for branch campuses added to the core campus figures for these schools with branch campuses. Thus, the current funds expenditures probably are somewhat underestimated, and thus represent a conservative criterion.

\subsection{DATA ON COLLEGES AND UNIVERSITIES THAT ARE NRC MATERIALS LICENSEES}

Exhibits 2-4 and 2-5 provide data on colleges and universities that the NRC License Tracking system (LTS) indicates must provide financial assurance. The exhibits were prepared by identifying colleges and universities listed in the LTS, prepared by NRC as of October, 1996. Information on whether the school is public or private, on endowment assets, and on endowment assets was obtained from the NACUBO 1995 endowment report, which presents the most recent available information. Information on bond ratings was obtained from a number of sources, including telephone calls to S\&P and Moody's, and use of Moody's Quarterly List of Higher Education Revenue Bond Ratings, current as of July 16, 1996. The ratings provided are for uninsured general obligation bonds, unless marked (I) (e.g., "AAA(I)"), in which case they are insured. Data on current funds expenditures was obtained from IPEDS.

As Exhibits 2-4.a and 2-5.a demonstrate, more public colleges and universities (40) are NRC materials licensees than private colleges and universities (24). A larger number of public schools possess endowments, though the endowments at private institutions are relatively larger. Similarly, a larger number of public colleges and universities have bond ratings. Depending on the cutoff points, however, self-guarantee tests involving an endowment criterion and a bond-rating criterion could be available to both public and private colleges and universities.

Exhibits 2-4.b and 2-5.b present data on the 33 colleges and universities that are NRC research reactor licensees, licensed under 10 CFR Part 50. About a third of these licensees also possess Part 30, 40, 70 or 72 licenses. NRC's Office of Nuclear Reactor Regulation (NRR) calculates the average decommissioning cost for a research reactor at approximately $\$ 2$ million. These Part 50 licensees use Statements of Intent, a mechanism imposing significantly smaller private costs that are essentially equivalent to the private costs of a self-guarantee. 
Exhibit 2-4.a

NRC College and University Materials Licensees

(Public) ( $\mathbf{N = 4 0 )}$

\begin{tabular}{|c|c|c|c|c|c|}
\hline '. & Wnownong & 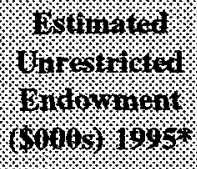 & 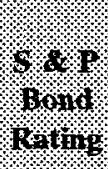 & Hownol & 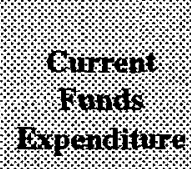 \\
\hline Texas A\&M University** & $\$ 2,220,016$ & $\$ 705,965$ & $A+$ & Aaa & $763,295,591$ \\
\hline University of Michigan** & $\$ 1,321,432$ & $\$ 420,215$ & AA & Aal & $1,868,539,629$ \\
\hline University of Virginia & $\$ 823,935$ & $\$ 262,011$ & AA & Aa1 & $767,378,719$ \\
\hline University of Minnesota** & $\$ 733,583$ & $\$ 233,279$ & AA & Aa & $1,887,167,894$ \\
\hline Purdue University & $\$ 603,686$ & $\$ 191,972$ & AA- & Aa & $727,283,214$ \\
\hline Ohio State University & $\$ 555,720$ & $\$ 176,719$ & AA- & Aa & $1,310,605,399$ \\
\hline University of Cincinnati & $\$ 496,052$ & $\$ 157,745$ & AA- & A1 & $745,848,304$ \\
\hline Indiana University** & $\$ 448,941$ & $\$ 142,763$ & AA- & $\mathrm{Aa}$ & $588,767,375$ \\
\hline Pennsylvania State University** & $\$ 338,472$ & $\$ 107,634$ & AA- & A1 & $739,099,370$ \\
\hline University of Florida & $\$ 334,801$ & $\$ 106,467$ & - & - & $790,970,391$ \\
\hline University of Missouri** & $\$ 324,400$ & $\$ 103,159$ & - & Aa & $594,756,333$ \\
\hline Rutgers, The State University of New Jersey & $\$ 228,425$ & $\$ 72,639$ & AA & A1 & - \\
\hline Virginia Polytechnic University & $\$ 188,241$ & $\$ 59,861$ & AA & A1 & $465,136,780$ \\
\hline University of Wisconsin** & $\$ 169,814$ & $\$ 54,001$ & - & - & $1,263,373,043$ \\
\hline Michigan State University & $\$ 128,065$ & $\$ 40,725$ & AA- & Aa & $820,176,721$ \\
\hline West Virginia University & $\$ 123,186$ & $\$ 39,173$ & - & - & $331,839,430$ \\
\hline University of Vermont & $\$ 110,682$ & $\$ 35,197$ & $A+$ & A1 & $236,010,000$ \\
\hline University of Alaska & $\$ 108,182$ & $\$ 34,402$ & AA- & A1 & $167,351,708$ \\
\hline Virginia Commonwealth University & $\$ 103,857$ & $\$ 33,027$ & AA- & A1 & $650,185,045$ \\
\hline Ohio University & $\$ 99,984$ & $\$ 31,795$ & - & A1 & $223,997,468$ \\
\hline University of Hawaii & $\$ 82,879$ & $\$ 26,356$ & - & - & $413,830,325$ \\
\hline University of Massachusetts** & $\$ 75,952$ & $\$ 24,153$ & - & - & $395,249,651$ \\
\hline New Jersey Univ. of Medicine and Dentistry & $\$ 72,563$ & $\$ 23,075$ & - & A & $674,483,692$ \\
\hline Wayne State University** & $\$ 70,000$ & $\$ 22,260$ & - & - & $409,979,919$ \\
\hline Oklahoma State University & $\$ 66,309$ & $\$ 21,086$ & $A+$ & A & $276,391,645$ \\
\hline University of Toledo & $\$ 56,704$ & $\$ 18,032$ & - & - & $181,203,884$ \\
\hline University of Idaho & $\$ 56,668$ & $\$ 18,020$ & - & A & $165,752,216$ \\
\hline
\end{tabular}


Exhibit 2-4.a (continued)

NRC College and University Materials Licensees

(Public) ( $\mathbf{N = 4 0 )}$

\begin{tabular}{|c|c|c|c|c|c|}
\hline אואו & 3. & 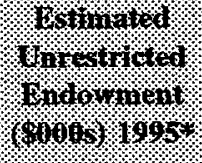 & 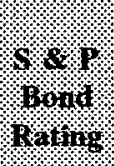 & 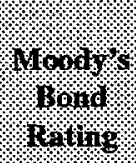 & 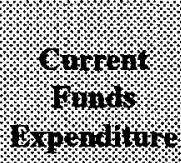 \\
\hline University of Wyoming & $\$ 54,757$ & $\$ 17,413$ & - & - & $190,318,057$ \\
\hline University of Connecticut & $\$ 47,361$ & $\$ 15,061$ & - & - & $362,364,299$ \\
\hline Western Michigan University & $\$ 38,810$ & $\$ 12,342$ & - & - & $239,354,528$ \\
\hline University of South Dakota & $\$ 28,212$ & $\$ 8,971$ & - & - & $37,591,529$ \\
\hline Medical College of Hampton Roads & $\$ 25,796$ & $\$ 8,203$ & A- & - & - \\
\hline Eastern Michigan University & $\$ 15,112$ & $\$ 4,806$ & - & - & $151,003,830$ \\
\hline Central Michigan State University & $\$ 12,321$ & $\$ 3,918$ & AAA & A & $167,137,961$ \\
\hline Idaho State University & - & - & - & A & $86,377,660$ \\
\hline Medical College of Ohio & - & - & - & - & $198,405,828$ \\
\hline Montana State University & - & - & - & - & $129,330,347$ \\
\hline University of Montana & - & - & - & - & $91,956,732$ \\
\hline University of Oklahoma** & - & - & A & A & $264,968,000$ \\
\hline Wright State University & - & - & - & - & - \\
\hline
\end{tabular}

* NACUBO statistics indicate that unrestricted endowment ("quasi" endowment) is about 31.7 percent of total endowment (dollarweighted mean) for all colleges and universities submitting information in 1995. This proportion was used to calculate estimated unrestricted endowment for individual public colleges and universities.

** $\quad$ More than one license 
Exhibit 2-4.b

NRC College and University Research Reactor Licensees

(Public) ( $\mathbf{N = 2 7 )}$

\begin{tabular}{|c|c|c|c|c|}
\hline 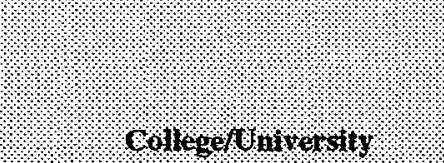 & toraroment & 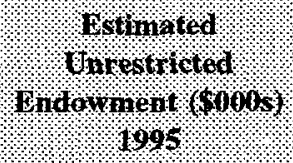 & 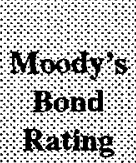 & 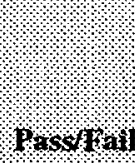 \\
\hline Georgia Institute of Technology & 335,516 & 106,694 & - & Pass \\
\hline Mdahostoternitersty & 10 & 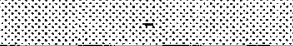 & 1 & Has \\
\hline Iowa State University & 135,490 & 43,086 & Al & Pass \\
\hline Kansas State University & 102,132 & 32,478 & A1 & Pass \\
\hline North Carolina State University & 138,631 & 44,085 & A1 & Pass \\
\hline 10110 staternutersily & $355 \% 20$ & 17671 & A & tass \\
\hline Oregon State University & 96,598 & 30,718 & - & Fail \\
\hline 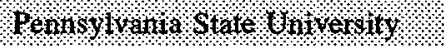 & 338,42 & 108631 & 11 & 195 \\
\hline 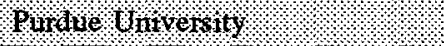 & 603680 & 191922 & Aa & 1ass \\
\hline SUNY Buffalo & 214,120 & 68,090 & - & Pass \\
\hline 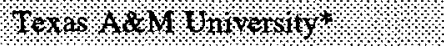 & 2220016 & 70596 & +14 & Pass \\
\hline University of Arizona & 81,405 & 25,887 & A1 & Pass \\
\hline U. California at Irvine & - & - & A1 & Pass \\
\hline Hnuersil of thorla & 394801 & 10,46 & 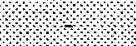 & 1ass \\
\hline University of Illinois* & 281,926 & 89,652 & $\mathrm{Aa}$ & Pass \\
\hline University of Mass, at Lowell & - & - & - & Fail \\
\hline University of Maryland & 169,081 & 53,768 & Aa & Pass \\
\hline dencersity 0 Wichinan & 1321432 & 420215 & $\mathrm{Aal}$ & $1+4 s$ \\
\hline University of Missouri/Rolla & - & - & - & Fail \\
\hline 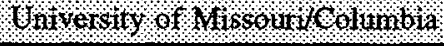 & 324,400 & 108159 & 4 & Pass \\
\hline University of New Mexico & 119,014 & 37,846 & $\mathrm{~A} 1$ & Pass \\
\hline University of Texas & $5,043,333$ & $1,603,780$ & Aal & Pass \\
\hline University of Utah* & 127,721 & 40,615 & - & Fail \\
\hline 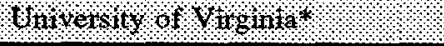 & 823035 & 262011 & 801 & 108 \\
\hline University of Washington & 359,508 & 114,324 & A & Pass \\
\hline Unversity 01 Wisconsin & 169614 & 54001 & 3 & Iass \\
\hline Washington State University & 262,833 & 83,581 & A1 & Pass \\
\hline
\end{tabular}

* More than one Part 50 license

Shading indicates college or university that appears in Exhibit 2-4.a. 
Exhibit 2-5.a

NRC College and University Materials Licensees

(Private) $(\mathbf{N}=\mathbf{2 4})$

\begin{tabular}{|c|c|c|c|c|c|}
\hline 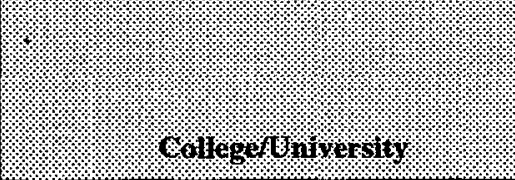 & 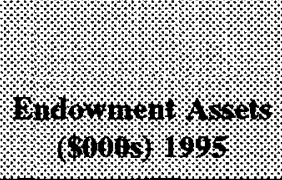 & 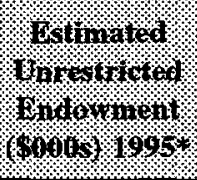 & \%ong & ?. & 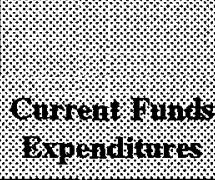 \\
\hline Harvard University** & $\$ 7,045,863$ & $\$ 2,233,539$ & AAA & Aaa & $1,262,269,000$ \\
\hline Yale University & $\$ 3,959,080$ & $\$ 1,255,028$ & AAA & Aaa & $799,262,466$ \\
\hline Princeton University** & $\$ 3,882,421$ & $\$ 1,230,727$ & AAA & Aaa & $496,800,000$ \\
\hline Massachusetts Institute of Technology & $\$ 2,078,414$ & $\$ 658,857$ & A & Aaa & $1,092,549,000$ \\
\hline University of Pennsylvania & $\$ 1,675,740$ & $\$ 531,210$ & $\mathbf{A A}$ & $\mathrm{Aa}$ & $1,381,305,000$ \\
\hline Notre Dame University & $\$ 996,895$ & $\$ 316,016$ & - & Aaa & $305,508,566$ \\
\hline Case Western Reserve University** & $\$ 620,929$ & $\$ 196,834$ & - & $\mathrm{Aa}$ & $297,891,000$ \\
\hline Boston College & $\$ 500,163$ & $\$ 158,552$ & - & A1 & $271,773,380$ \\
\hline University of Pittsburgh & $\$ 461,002$ & $\$ 146,138$ & - & - & $718,202,441$ \\
\hline Georgetown University & $\$ 413,264$ & $\$ 131,005$ & - & A1 & $717,625,000$ \\
\hline The George Washington University & $\$ 398,141$ & $\$ 126,211$ & - & A1 & $578,241,660$ \\
\hline Saint Louis University & $\$ 388,013$ & $\$ 123,000$ & - & A & $436,077,344$ \\
\hline Lehigh University & $\$ 380,154$ & $\$ 120,509$ & $A+$ & - & $185,361,000$ \\
\hline Brandeis University & $\$ 210,665$ & $\$ 66,781$ & - & - & $132,391,788$ \\
\hline Howard University & $\$ 152,191$ & $\$ 48,245$ & A+ & A & $461,857,690$ \\
\hline Marquette University & $\$ 142,188$ & $\$ 45,074$ & - & - & $146,871,065$ \\
\hline Miami University (Ohio) & $\$ 97,808$ & $\$ 31,005$ & $A+$ & - & $198,405,828$ \\
\hline Carnegie-Mellon University & - & - & AA- & - & $317,217,000$ \\
\hline Catholic University of America** & - & - & - & - & $101,395,719$ \\
\hline Cleveland State University & - & - & - & - & $137,304,685$ \\
\hline Marshall University & - & - & - & - & - \\
\hline Old Dominion University & - & - & - & - & $125,861,484$ \\
\hline Tufts University School of Medicine & - & - & - & - & $266,344,599$ \\
\hline University of Puerto Rico & - & - & $* * *(\mathbf{I})$ & A & - \\
\hline
\end{tabular}

* NACUBO statistics indicate that unrestricted endowment ("quasi" endowment) is about 31.7 percent of total endowment (dollarweighted mean) for all colleges and universities submitting information in 1995. This proportion was used to calculate estimated unrestricted endowment for individual private colleges and universities.

*** More than one license

*** (I) Indicates insured bond 
Exhibit 2-5.b

NRC College and University Research Reactor Licensees

(Private) (N=6)

\begin{tabular}{|c|c|c|c|c|}
\hline Collegronvorsit) & 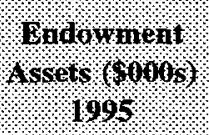 & 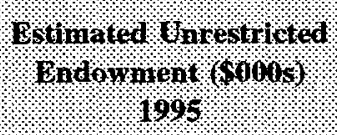 & Bond haldo & $10081+1 \%$ \\
\hline Cornell University* & $1,475,577$ & 467,758 & $\mathrm{Aa}$ & Pass \\
\hline Manhattan College & - & - & - & Fail \\
\hline Mossachusets Insthite of Technolog) & 2018414 & 658857 & 1ar & Pas \\
\hline Reed College & 151,717 & 48,094 & - & Fail \\
\hline Rennselaer Polytechnic Institute & 311,630 & 98,787 & A & Pass \\
\hline Worcester Polytechnic Institute & 142,248 & 45,093 & A & Pass \\
\hline
\end{tabular}

* More than one Part 50 license

** Pass/Fail determinations were made using actual data on decommissioning costs for Worcester Polytechnic Institute, Rennselaer Polytechnic Institute, Reed College, Cornell University, and the Massachusetts Institute of Technology.

Shading indicates college or university that appears in Exhibit 2-5.a.

\subsection{EVALUATION OF ALTERNATIVE THRESHOLDS}

The impacts on self-guarantee availability to materials licensees that are colleges and universities were tested for a range of different test configurations and threshold values. They included the following:

- Bond rating criterion plus size criterion, measured as current funds expenditures;

- Bond rating criterion plus assets criterion, measured as endowment assets;

- $\quad$ Bond rating criterion plus assets criterion, measured as unrestricted endowment assets; and

- Size criterion, measured as current funds expenditures, plus assets criterion, measured as endowment assets.

Within these major test configurations, several variations in the criteria were investigated. For tests involving bond ratings, the effect of allowing insured bonds was evaluated. For tests involving endowment assets, a number of alternative thresholds were evaluated, based on the size of an endowment necessary to obtain two alternative levels of decommissioning funding, $\$ 900,000$ and $\$ 1.5$ million, with an estimated $12 \%$ rate of return for endowment investment and an estimated cap of 5\% on annual spending from endowment assets. (E.g., if no more than $5 \%$ of existing endowment assets can be spent for any purpose in one year, how large must the endowment be to allow an expenditure of $\$ 1.5$ million for decommissioning?) 


\subsubsection{Alternative One: Bond Rating Criterion Plus Current Funds Expenditures Requirement}

This alternative would require a college or university to have a bond rating of $\mathrm{A}$ or better, and to show that based on its most recent current funds expenditures it would have to reallocate only a relatively low percentage of its annual current funds expenditures to fund decommissioning. The percentages tested ranged from $5 \%(.05)$ to $0.25 \%(.0025)$ of annual current funds expenditures, based on a decommissioning estimate of $\$ 1.5$ million. Exhibit 2-6 provides the results for this alternative.

\section{Exhibit 2-6}

Numbers of NRC College and University Licensees ( $N=64)$

With A or Better Bond Rating and Current Funds Expenditures (CFE) Exceeding Alternative Thresholds

\begin{tabular}{|c|c|c|c|c|}
\hline \multirow[b]{2}{*}{ Public } & $\$ 30 \mathrm{M} \mathrm{CFE}{ }^{\mathrm{a}}$ & $\$ 150 \mathrm{M} \mathrm{CFE}^{\mathrm{b}}$ & $\$ 300 \mathrm{M} \mathrm{CFE}^{\mathrm{c}}$ & $\$ 600 \mathrm{M} \mathrm{CFE}^{\mathrm{d}}$ \\
\hline & 22 & 21 & 14 & 11 \\
\hline Private & 15 & 15 & 11 & 5 \\
\hline \multirow[t]{2}{*}{ Total } & 37 & 36 & 25 & 16 \\
\hline & \multicolumn{4}{|c|}{$\begin{array}{ll}\text { a } & 5 \% \text { of } \$ 30 \mathrm{M} \text { CFE }=\$ 1.5 \mathrm{M} \\
\text { b } & 1 \% \text { of } \$ 150 \mathrm{M} \text { CFE }=\$ 1.5 \mathrm{M} \\
\text { c } & 0.5 \% \text { of } \$ 300 \mathrm{M} \mathrm{CFE}=\$ 1.5 \mathrm{M} \\
\text { d } & 0.25 \% \text { of } \$ 600 \mathrm{M} \text { CFE }=\$ 1.5 \mathrm{M}\end{array}$} \\
\hline
\end{tabular}

This alternative also was tested allowing insured bonds to pass the bond rating criterion. Doing so did not cause additional colleges or universities to pass the test.

\subsubsection{Alternative Two: Bond Rating Plus Endowment Requirement}

This alternative would require a college or university to have an A or better bond rating and to show that based on its current endowment it would have to expend only one year's endowment income or, alternatively, one year's allowable expenditures from endowment to fund decommissioning. ${ }^{32}$ Using $\$ 900,000$ and $\$ 1.5$ million as cost estimates for decommissioning, the number of NRC licensees that might be able to qualify to use the self-guarantee was calculated. The results are provided in Exhibit 2-7. As the exhibit demonstrates, out of about 64 licensees, between 29 to 35 licensees (about 45 percent to 55 percent of the group) might be able to qualify, based on the endowment size required. Of these, a greater number would be public rather than private colleges and universities.

32 Income was based on the 1994 rate of return ( 3 percent) and the ten-year average rate of return (about 12 percent), as calculated by NACUBO; allowable expenditures was based on a 5 percent cap on expenditures (see footnotes 26 and 27). 


\section{Exhibit 2-7}

Numbers of NRC College and University Licensees $(N=64)$

With A or Better Bond Rating and Endowment (E) Exceeding Alternative Thresholds

\begin{tabular}{|c|c|c|c|c|c|c|c|}
\hline & $\$ 7.5 \mathrm{M} \mathrm{E} E^{\mathrm{a}}$ & $\$ 12.5 \mathrm{M} \mathrm{E}^{\mathrm{b}}$ & $\$ 18 \mathrm{M} \mathrm{E}^{\mathrm{c}}$ & $\$ 30 \mathrm{M} \mathrm{E} \mathrm{E}^{\mathrm{d}}$ & $\$ 50 \mathrm{M} \mathrm{E}^{\mathrm{e}}$ & $\$ 60 \mathrm{ME}^{\mathrm{f}}$ & $\$ 100 \mathrm{M} \mathrm{E}^{\mathrm{g}}$ \\
\hline Public & 21 & 20 & 20 & 20 & 20 & 19 & 16 \\
\hline Private & 14 & 14 & 14 & 14 & 14 & 14 & 13 \\
\hline Total & 35 & 34 & 34 & 34 & 34 & 33 & 29 \\
\hline $\begin{array}{cc}\text { a } & \text { Endow } \\
\text { c } & \text { Endow } \\
\text { c } & \text { Endow } \\
\text { d } & \text { Endow } \\
& \text { to } \\
\text { e } & \text { Endow } \\
\mathrm{f} & \text { Endow } \\
\mathrm{g} & \text { Endow }\end{array}$ & $\begin{array}{l}\text { ent necessar } \\
\text { ent necessar } \\
\text { ent necessar } \\
\text { ent necessar } \\
\text { in } \$ 900,000 \\
\text { ent necessar } \\
\text { ent necessar } \\
\text { ent necessar }\end{array}$ & $\begin{array}{l}\text { to pay } \$ 900,0 \\
\text { to pay } \$ 1.5 \mathrm{M} \\
\text { to pay } \$ 900,0 \\
\text { to pay } \$ 1.5 \mathrm{M} \\
\text { one year at } \\
\text { to earn } \$ 1.5 \mathrm{M} \\
\text { to pay } \$ 1.5 \mathrm{M} \\
\text { to earn } \$ 1.5 \mathrm{M}\end{array}$ & $\begin{array}{l}\text { in one yea } \\
n \text { one year } \\
\text { in one yea } \\
n \text { one year } \\
6 \text { return; } \\
\text { in one year } \\
n \text { one year } \\
\text { in one year }\end{array}$ & $\begin{array}{l}12 \% \text { retur } \\
12 \% \text { return; } \\
\text { with } 5 \% \text { spe } \\
\text { th } 5 \% \text { spenc } \\
3 \% \text { return; } \\
\text { pending hal } \\
3 \% \text { return }\end{array}$ & $\begin{array}{l}\text { ling cap; } \\
\text { ig cap; or en } \\
\text { of } 5 \% \text { spendi } \\
\text { th equivalen }\end{array}$ & $\begin{array}{l}\text { lowment ne } \\
\text { g cap; } \\
\text { remaining }\end{array}$ & $\begin{array}{l}\text { ssary } \\
\text { lance. }\end{array}$ \\
\hline
\end{tabular}

The effect of allowing insured bonds to be used was also estimated. Doing so would not cause any additional colleges and universities to pass the test.

\subsubsection{Alternative Three: Endowment Criterion and Current Funds Expenditure Requirement}

This alternative would require a college or university to demonstrate both that it possessed endowment of at least a specified size and that its current funds expenditures exceeded a specified threshold. This alternative represents a case in which the college or university might be expected to pay for decommissioning out of endowment, by redirecting current expenditures, or by a combination of the two approaches. It does not, however, have any test component that is a third-party assessment of the financial strength of the institution, due to the absence of any bond rating criterion.

Exhibit 2-8 presents the results for this alternative, at selected threshold levels tested for Alternatives One and Two. 
Exhibit 2-8

Numbers of NRC College and University Licensees ( $N=64)$

With Endowment (E) and Current Funds Expenditures (CFE)

Exceeding Alternative Thresholds

\begin{tabular}{|c|c|c|c|c|c|}
\hline & $\begin{array}{c}\mathrm{E}=\$ 12.5 \mathrm{M} \\
\mathrm{CFE}=\$ 30 \mathrm{M}\end{array}$ & $\begin{array}{c}E=\$ 18 \mathrm{M} \\
\mathrm{CFE}=\$ 30 \mathrm{M}\end{array}$ & $\begin{array}{c}E=\$ 30 \mathrm{M} \\
\mathrm{CFE}=\$ 150 \mathrm{M}\end{array}$ & $\begin{array}{c}E=\$ 60 \mathrm{M} \\
\mathrm{CFE}=\$ 300 \mathrm{M}\end{array}$ & $\begin{array}{c}E=\$ 100 \mathrm{M} \\
\mathrm{CFE}=\$ 600 \mathrm{M}\end{array}$ \\
\hline Public & 31 & 30 & 29 & 20 & 12 \\
\hline Private & 17 & 17 & 15 & 11 & 6 \\
\hline Total & 48 & 47 & 44 & 31 & 18 \\
\hline
\end{tabular}

\subsubsection{Alternative Four: Bond Rating or Unrestricted Endowment Requirement}

This alternative would allow a college or university to qualify for use of the self-guarantee by having an $\mathrm{A}$ or better bond rating or to show that it possesses unrestricted endowment (i.e., endowment whose principal may be expended at the discretion of the institution's governing board) of at least $\$ 50$ million or alternatively unrestricted endowment at least 30 times its decommissioning costs. Because 30 times either $\$ 900,000$ or $\$ 1.5$ million is less than $\$ 50$ million, if an individual college or university had an unrestricted endowment greater than or equal to $\$ 50$ million, it was considered able to pass. This analysis, therefore, may tend to overstate its number of schools able to pass using this test, if decommissioning costs substantially exceed $\$ 1.5$ million. However, the number of schools with an unrestricted endowment greater than $\$ 50$ million but less than 30 times their decommissioning costs is likely to be quite small. Exhibit 2-9 presents the results for this alternative.

\section{Exhibit 2-9}

Numbers of NRC College and University Licensees ( $N=64)$

With A or Better Rating or Unrestricted Endowment (UE) Exceeding $\$ 50$ Million

\begin{tabular}{||c|c|c|c|c||}
\hline \multicolumn{1}{|c|}{} & \multicolumn{1}{|c|}{$\begin{array}{c}\text { \$50 } \\
\text { A or } \\
\text { Better } \\
\text { Only } \\
\text { UE } \\
\text { Onlion } \\
\text { Only }\end{array}$} & Both & Total \\
\cline { 2 - 5 } & 11 & 2 & 12 & 25 \\
\hline Private & 4 & 2 & 12 & 18 \\
\hline & 15 & 3 & 24 & 43 \\
\hline
\end{tabular}


Of the 27 public colleges and universities with NRC Part 50 licensees, 23 would qualify for use of the self-guarantee. (See Exhibit 2-4.b) It is unlikely, however, that any of these institutions will assume the cost of such a mechanism, when they are all eligible to issue statements of intent. Statements of intent impose negligible costs on their issuers.

Of the six private colleges and universities with NRC Part 50 licensees, four (Cornell University, Rennselaer Polytechnic Institute, Worcester Polytechnic Institute, and the Massachusetts Institute of Technology) would qualify for use of the self-guarantee. All of the qualifying institutions have an $\mathrm{A}$ or better bond rating and three of four have unresticted endowments in excess of 30 times their decommissioning costs as well as a minimum unrestricted endowment of $\$ 50,000,000$. Actual decommissioning costs were used to determine whether or not the institutions met this requirement. Only Worcester Polytechnic Institute qualifies for the self-guarantee on the basis of the bond rating alone. (See Exhibit 2-5.b)

\subsection{SUMMARY}

Exhibit 2-10 presents a comparison of the test alternatives, showing the number of Part 30,40, 70 , and 72 licensees that may be able to pass alternative tests at equivalent degrees of stringency.

Exhibit 2-10

Comparison of Alternative Self-Guarantee Tests for Colleges and Universities

\begin{tabular}{|c|c|c|}
\hline Degree of Stringency & Test Alternatives & $\begin{array}{l}\text { Licensees Passing } \\
\text { (out of 64) }\end{array}$ \\
\hline Low & $\begin{array}{l}\text { Alternative } 1 \text { : } \\
\text { "A" Bond rating + CFE }>\$ 30 \mathrm{M} \\
\text { Alternative } 2 \text { : } \\
\text { "A" Bond rating }+\mathrm{E}>\$ 12.5 \mathrm{M} \\
\text { Alternative } 3: \\
\mathrm{E}>\$ 12.5 \mathrm{M}+\mathrm{CFE}>\$ 30 \mathrm{M}\end{array}$ & $\begin{array}{l}37 \\
34 \\
48\end{array}$ \\
\hline Moderate & $\begin{array}{l}\text { Alternative } 1 \text { : } \\
\text { "A" Bond rating + CFE }>\$ 150 \mathrm{M} \\
\text { Alternative } 2 \text { : } \\
\text { "A" Bond rating + E > } \$ 60 \mathrm{M} \\
\text { Alternative 3: } \\
E>\$ 60 \mathrm{M}+\mathrm{CFE}>\$ 300 \mathrm{M}\end{array}$ & $\begin{array}{l}36 \\
33 \\
31\end{array}$ \\
\hline High & $\begin{array}{l}\text { Alternative 1: } \\
\text { "A" Bond rating + CFE }>\$ 600 \mathrm{M} \\
\text { Alternative 2: } \\
\text { "A" Bond rating }+\mathrm{E}>\$ 100 \mathrm{M} \\
\text { Alternative } 3 \text { : } \\
\mathrm{E}>\$ 100 \mathrm{M}+\mathrm{CFE}>\$ 600 \mathrm{M} \\
\text { Alternative 4: } \\
\text { "A" Bond rating or (UE) }>\$ 50 \mathrm{M}\end{array}$ & $\begin{array}{l}16 \\
29 \\
18 \\
43\end{array}$ \\
\hline
\end{tabular}




\section{ANALYSIS OF POTENTIAL SELF-GUARANTEE TESTS FOR DEMONSTRATING FINANCIAL ASSURANCE BY HOSPITALS}

This section presents an outline of the structure and provisions of a potential self-guarantee test for nonprofit hospitals. ${ }^{1}$ To parallel self-guarantee criteria for colleges and universities, a selfguarantee test for hospitals should include both a bond rating alternative and a non-bond rating alternative. Although the two alternatives would differ with respect to certain criteria, they would share a number of common provisions. The following subsections present and describe a possible design for the hospital self-guarantee test:

- Section 3.1 summarizes provisions that may be appropriate to include in the hospital self-guarantee test.

- Section 3.2 provides a more detailed discussion of the bond rating criterion.

- Section 3.3 discusses the anticipated provisions of a non-bond rating alternative.

- Section 3.4 details certain requirements appropriate for inclusion in both test alternatives.

- $\quad$ Section 3.5 presents data on nonprofit hospitals that are NRC materials licensees.

- Section 3.6 estimates the availability of the bond rating alternative and the non-bond rating alternative under different thresholds for a financial size criterion.

- $\quad$ Section 3.7 provides a summary comparing the numbers of hospitals that may be capable of passing the test alternatives at different levels of stringency.

\subsection{SUMMARY OF POSSIBLE TEST DESIGN}

A self-guarantee test for hospitals could be structured to include criteria that parallel NRC's existing test for corporate parent guarantors, which includes both a bond rating alternative and a nonbond rating alternative for those parents that have not issued rated general obligation bonds. ${ }^{2}$ The

\footnotetext{
${ }^{1}$ Although the objective of this study was to develop self-guarantee criteria for nonprofit hospitals, the criteria recommended could also be applicable to for-profit hospitals. In addition to hospitals, two categories of health-related organizations that may be NRC materials licensees required to provide financial assurance are (1) teaching institutions, either independent or affiliated with universities, and (2) independent research institutes. Although this analysis concentrated on nonprofit hospitals, the other two categories were also considered, as discussed in this section.

${ }^{2}$ NRC's existing test for self-guarantors does not include a non-bond alternative. Among other alternative tests, this analysis evaluates self-guarantee tests for hospitals that do not issue bonds.
} 
two alternatives would differ with respect to certain criteria, but could share a number of common provisions, selected from the following potential types of criteria:

\section{Bond Rating Criterion}

- Self-guarantor must have a current minimum bond rating (e.g., A or better as issued by Standard and Poor's or Moody's) on its most recent bond issuance. ${ }^{3}$

\section{Non-Bond Rating Criterion}

- $\quad$ Self-guarantor must rank above a certain level in each of certain financial categories.

- $\quad$ Self-guarantor must submit to NRC a letter from an independent certified public accountant which states that the accountant has compared the licensee's audited financial statements for the most recently completed fiscal year with the letter from its Chief Financial Officer (CFO) confirming the licensee's Medicare cost reports filed with the Health Care Financing Administration (HCFA), and that the figures reported in the letter for certain items are identical to the figures found in the audited financial statements.

\section{Minimum Size Criterion}

- $\quad$ Self-guarantor must meet a minimum size requirement (e.g., minimum operating revenue) for the most recently completed fiscal year.

- Self-guarantor must prepare audited annual financial statements in accordance with generally accepted accounting principles for hospitals. These financial statements, including the opinion from the independent certified public accountant conducting the audit, must be included in the self-guarantee documentation submitted to $\mathrm{NRC}^{4}$

The basis for this recommended design is described in the balance of this section.

\subsection{BOND RATING CRITERION}

Bond ratings are widely used as a measure of credit risk associated with long-term debt instruments. Ratings agencies strive to be unbiased, and put forth considerable effort in determining the financial health and strength of bond issuers when assessing this credit risk. Bonds are also rerated on a periodic basis. In order to receive an investment grade bond rating, a bond issuer must

\footnotetext{
${ }^{3}$ This alternative could require that the bond issuance not have credit enhancement such as a bank letter of credit or bond insurance policy, or ratings on insured bonds could be allowed.

4 NRC would need to determine whether annual financial test updates would have to be submitted to NRC for review. NRC's corporate self-guarantee (found in Appendix B to 10 CFR Part 30) does not specifically require such updates to be submitted to NRC for review, although it does require self-guarantors to (1) "repeat passage of the test within 90 days after the close of each succeeding fiscal year," and (2) "promptly forward to the Commission and the licensee's independent auditor all reports covering the latest fiscal year filed by the licensee with the Securities and Exchange Commission pursuant to the requirements of section 13 of the Securities and Exchange Act of 1934."
} 
demonstrate a record of adequate financial management and accounting controls, strong operations, and an ability to repay the bond holders.

Nonprofit hospitals are allowed to use tax-exempt bond financing and these bonds are often rated by independent rating agencies such as S\&P and Moody's. Combined, these two rating agencies provide ratings on nearly half of all hospitals in the U.S. ${ }^{5}$ In the process of rating hospital bonds, rating agencies conduct a comprehensive examination of the hospital's financial status and creditworthiness. The rating agency generally undertakes a site visit ${ }^{6}$ and scrutinizes factors such as competition, management capability, and project development. ${ }^{7}$ Following the initial assignment of a rating, the agency continues to follow these factors in order to rerate the bonds if necessary.

Some hospital's bonds are backed by collateral or by a guarantor. ${ }^{8}$ A hospital's bond rating may fail to adequately reflect its financial strength if the bond is backed by collateral (e.g., collateralized bonds). In this case, the rating may reflect the strength of the collateral more than the strength of the hospital. Similarly, bond rating agencies view guaranteed debt as being the direct debt of the guarantor. Therefore, the bond rating process focuses on the guarantor (perhaps a multihospital system of which the issuing hospital is a member), and the assigned rating reflects the underlying financial strength of the guarantor rather than the hospital issuing the debt. From NRC's perspective, a rating on guaranteed debt may be appropriate for purposes of a parent company guarantee, but seems inapplicable to a self-guarantee test because the guarantor would not be the licensee.

Some hospital bonds are guaranteed by a bond insurance company. Although ratings on insured bonds reflect. the financial strength of the insurer rather than the issuer, ${ }^{9}$ bond insurance companies evaluate the financial condition of the issuers they insure and avoid issuing policies to entities that are not creditworthy. Consequently, the presence of bond insurance (and the triple-A rating that accompanies it) may indicate that a hospital is in sound financial condition. ${ }^{10}$ Ratings on insured bonds do not, however, fluctuate as the financial condition of the issuer changes. If an issuer's financial condition deteriorates, the rating on its insured bonds remains constant. Bond insurers monitor the financial condition of issuers for as long as insured bonds are outstanding. If this

5 Joen Goetz, Moody's vice president for public finance and health care ratings, as quoted by Clements, "How to Read a Hospital's Financial Health," American Medical News, April 27, 1992.

6 Nemes, J., "Hospitals Signaling Distress," Modern Healthcare, March 4, 1991.

7 "S\&P: Anatomy of Four Recent Hospital Bond Defaults," Hospitals, August 5, 1990.

8 Lumsdon, K., "Bond Update: Slowing But Continued Deterioration," Healthcare Financial Management, September 1990; Sherman, B., "How Investors Evaluate the Creditworthiness of Hospitals," Healthcare Financial Management, March 1990.

9 Bonds that are insured by one of the major bond insurance companies are automatically rated Aaa by Moody's and AAA by Standard \& Poor's based on the financial strength of the insurer, which must maintain an Aaa or AAA rating itself.

10 Bond insurance, however, can also be obtained for structured financings. Structured bonds are secured at least in part by some type of collateral (e.g., a letter of credit) or guarantee. The underwriting process that insurers use for this type of bond may assess only the security of the collateral, and not the financial condition of the issuer. Consequently, it would probably not be appropriate for purposes of a financial test to accept ratings on structured issues. 
surveillance causes the insurer to believe that an issuer may be in jeopardy of defaulting on insured debt payments, the insurer may advise the issuer of ways to improve its financial condition and avoid default.

For purposes of a self-guarantee test, ratings should be current ratings on a hospital's most recent bond issuance that is not collateralized, guaranteed, or insured. Acceptance of ratings of A or better, as issued by Standard and Poor's or Moody's, would establish a threshold consistent with NRC's corporate self-guarantee test. ${ }^{11}$

\subsection{POTENTIAL CRITERIA FOR NON-BOND RATING ALTERNATIVE}

All hospitals participating in the federally-assisted Medicare program (this includes virtually all hospitals) must file a Medicare Cost Report (MCR) annually with the Health Care Financing Administration (HCFA) of the U.S. Department of Health and Human Services. MCRs provide highly detailed financial and operational data on a hospital's performance for a given year (a typical MCR may exceed 200 pages in length), including much of the same data found in hospitals' annual financial statements. ${ }^{12}$ ICF has identified commercial vendors that collect, process, and compile MCR data submitted by hospitals. One of these vendors, HCIA Incorporated, located in Baltimore, Maryland, publishes an annual directory (Profiles of U.S. Hospitals) that uses MCR data to classify all hospitals having at least 50 beds according to several financial criteria, including the following:

- $\quad$ "Liquidity," measured by the current ratio (current assets divided by current liabilities);

- $\quad$ Net revenue (or "profitability"), measured as the difference between total revenue (operating and non-operating) and total expense, divided by total revenue; ${ }^{13}$ and

11 Consistent with NRC's current corporate self-guarantee, hospitals would fail the criterion if rated "A-" or below by S\&P and Moody's.

${ }^{12}$ MCR data is identical to the data in audited financial statements for almost all hospitals. Nevertheless, a condition can be added to the self-guarantee test to ensure that relevant data used in the self-guarantee are identical to the data in the annual financial statements. Such a requirement would be analogous to the "special report" required under NRC's corporate self-guarantee and parent company guarantee.

${ }^{13}$ The term "net revenue" is used to refer to the difference between a nonprofit entity's total revenue and its total expenditures. The same measure is generally called "profit" when referring to a for-profit entity. This study uses the term "profitability" in order to be consistent with the terminology used by HCIA, even though "net revenue" is technically correct and appropriately connotes the not-for-profit objectives held by nonprofit hospitals. Even for nonprofit hospitals, however, it is important that net revenue be substantially positive. No entity, whether for-profit or nonprofit, can survive over time if net revenue is usually negative. Entities that must maintain significant capital investments, such as hospitals, must earn net revenue that is sufficient both to replace aging capital stock and to protect it from the effects of economic downturns and fiscal emergencies. The measure of net revenue calculated by HCIA, for example, is carefully evaluated by Standard \& Poor's when it determines bonds ratings for nonprofit hospitals. According to Standard \& Poor's, net revenue to total revenue of 5.5 percent is typical of a hospital with an " $\mathrm{A}$ " bond rating. In addition, the controller of a large nonprofit hospital system maintained, in a telephone conversation with ICF staff, that there is no significant difference in the level of net revenues sought by nonprofit hospitals relative to for-profit hospitals (excluding the most

(continued...) 
- $\quad$ "Leverage," measured by the ratio of long-term debt to net fixed assets (property, plant, and equipment net of accumulated depreciation).

Classifications are based on decile rankings. Thus, all hospitals in the top 10 percent for a given criterion receive a " 1 " for that criterion. Hospitals in the bottom 10 percent receive a "10." The liquidity, profitability, and leverage criteria measure the same types of financial characteristics as many of the measures that are most prominent in the financial literature. ${ }^{14}$ Thus, consistently high rankings across each of these three financial characteristics may serve as an effective indicator of financial condition for hospitals without rated debt.

Rankings of 1-5, in particular, indicate that a given hospital is in the top 50 percent of all U.S. hospitals, and rankings of 1-5 in all three categories demonstrates financial health in a broad context. Far fewer than 50 percent of hospitals rank in the top 50 percent in all three categories.

A rank of 5 also generally corresponds to the minimum score (i.e., on the underlying measure being ranked) that a hospital would need to earn a bond rating of " $\mathrm{A}$ " or better. For example, A-rated hospitals generally must maintain liquidity of about 2.5 percent as measured by the current ratio. Liquidity rankings of 1-5 apply only to hospitals with current ratio scores of 2.51 or higher. However, a bond rating criterion of $\mathrm{A}$ or better becomes somewhat more stringent when additional factors considered by the bond rating agencies are included.

\subsection{POTENTIAL CRITERIA FOR BOTH BOND RATING NON-BOND RATING ALTERNATIVES}

Certain criteria could be appropriate for both bond rating and non-bond rating test alternatives. In particular, both alternatives could include a minimum size requirement and/or accounting and financial reporting requirements. Several other shared requirements (summarized in Section 3.1) are identical or equivalent to requirements found in existing NRC guarantees, and are not addressed further in this section.

\section{$\underline{\text { Minimum Size Requirement }}$}

A hospital's size is an important determinant of financial strength as well as a key predictor of its financial health. Studies of hospital closures have found that small size is frequently associated with hospital closures or lack of financial flexibility. ${ }^{15}$ Bond insurance companies also consider size

\footnotetext{
${ }^{13}$ (...continued)

aggressive for-profits and possibly some small nonprofits). Based on a sample of 60 hospitals selected from HCIA's Profiles of U.S. Hospitals, it appears there is little or no difference in "profitability" between nonprofit hospitals and all U.S. hospitals.

${ }^{14}$ In 1994, ICF reviewed several recently published studies and collected information about the financial characteristics that they focused upon as financial indicators. HCIA also ranks each hospital's relative "efficiency," measured using a ratio of adjusted expense per equivalent discharge. A review of the financial literature uncovered less support for this measure relative to the other measures discussed above.

${ }^{15}$ Cleverley, W.O., "More Efficient Hospitals are Closing," Healthcare Financial Management, April 1993; Cleverley, W.O., "Predicting Hospital Failure With the Financial Flexibility Index," Healthcare Financial
} (continued...) 
measures in determining a hospital's qualifications for bond insurance. ${ }^{16} \mathrm{~A} \$ 750,000$ decommissioning cost will be a far more significant expense for a small hospital than for a large one. To large hospitals, such a cost may represent only a small fraction of revenue, and may not require any significant disruptions in services. Similarly, banks are willing to extend more credit to larger hospitals than to smaller ones, all else equal, because larger hospitals can repay larger loans with the same effort that it takes smaller hospitals to repay smaller loans.

NRC requires firms providing parent company guarantees to meet a minimum size criterion of at least $\$ 10$ million in tangible net worth. A review of hospital financial studies indicates that size measures are an important consideration in evaluating hospital financial conditions, and would be an important component of a hospital self-guarantee test. A size measure could be based upon financial characteristics, such as operating revenue or total revenue, or upon operational characteristics such as number of beds, or the number of patients served per day. Size measures examined in this analysis are described in Sections 3.5 and 3.6.

\section{Accounting and Financial Reporting Requirements}

Accounting and financial reporting practices of nonprofit hospitals are important to a selfguarantee test for several reasons. First, unless hospital accounting practices are sufficiently standardized, the financial variables used by the test might differ in meaning for different hospitals, calling into question the feasibility of a self-guarantee test. Second, if the accounting system of a particular hospital happens to deviate from standard hospital practices, then that hospital's performance on the self-guarantee test may have little significance. Third, if the financial variables used in the test are not already prepared and reported by hospitals for other purposes (e.g., for a publicly available annual report), the variables may be relatively difficult or costly for a hospital to prepare and for NRC to verify.

NRC's two current financial tests for the parent company guarantee and the corporate selfguarantee satisfy these considerations by drawing upon financial data that has been (1) audited by an independent certified public accountant, (2) found to have been prepared in accordance with generally accepted accounting principles, and (3) reported in the guarantor's annual financial statements. These requirements also seem appropriate for a self-guarantee test for hospitals.

\section{Nonprofit Hospital Accounting Practices}

Generally Accepted Accounting Principles (GAAP) do exist for nonprofit hospitals, just as they do for profit-oriented corporations (although GAAP for nonprofit hospitals differs from GAAP for corporations). These voluntary accounting principles ensure significant standardization in the accounting systems and financial data of entities that comply with them. It is common practice for nonprofit hospitals (or systems composed of two or more hospitals) to have their financial statements

\footnotetext{
${ }^{15}$ (...continued)

Management, May 1985. Hospital Closure: 1988, March 1990; Hospital Closure: 1989, January 1991; Hospital Closure: 1990, January 1992; Standard \& Poor's Credit Overview: Municipal Ratings, November 1983.

16 "Healthcare Underwriting Criteria," Municipal Bond Investors Assurance Corporation, 1995. "Hospital Underwriting Criteria," AMBAC Investors Corporation, 1995.
} 
audited annually for compliance with GAAP by an independent auditor. ${ }^{17}$ In general, therefore, nonprofit hospitals that wish to use the self-guarantee test will not have to undertake the expense of an audit just for purposes of a self-guarantee test.

The authoritative source for GAAP for nonprofit hospitals is the Financial Accounting Standards Board (FASB). ${ }^{18}$ Generally accepted accounting principles for nonprofit hospitals differ from GAAP for most corporations in several significant ways. ${ }^{19}$ For example, nonprofit hospitals frequently receive contributions from donors. These contributions may have permanent restrictions governing their use, temporary restrictions, or they may be unrestricted. FASB requires nonprofit entities to distinguish among contributions that increase each of these asset types. FASB further requires such entities to recognize the expiration of donor-imposed restrictions in the period in which the restrictions expire (i.e., when the stipulated time has lapsed or when the stipulated purpose for which the resource was restricted has been fulfilled, or both). If the stipulated time has lapsed and no expense has been incurred, the asset is reclassified as an unrestricted asset. ${ }^{20}$

Nonprofit hospitals may also generate unrestricted assets through revenues, gains, and contributions. The increase in unrestricted net assets (also called "change in equity") in any given year is traditionally thought of as being the "bottom line" for nonprofit entities. ${ }^{21}$

\section{Nonprofit Hospital Financial Reporting Practices}

As discussed in Section 2.4, FASB issued new standards for the financial reporting of nonprofit organizations in June 1993. The new standards, effective for fiscal years beginning after December 15, 1994, state that a complete set of financial statements for nonprofit hospitals will include a statement of financial position (or balance sheet), a statement of activities, a statement of cash flow, and accompanying notes.

Although the exact effect of the changes will be somewhat unclear until after they have been widely implemented, most commentators appear to believe that the impact of FAS 116 and 117 will be much more apparent with respect to colleges and universities than with respect to hospitals. Nonprofit hospitals will have limited flexibility in the precise format and presentation of their financial statements. $^{22}$ This flexibility does not, however, pose a threat to NRC's ability to administer a selfguarantee test for nonprofit hospitals.

17 Telephone conversation with William R. Titera, CPA, Ernst \& Young, May 9, 1994.

18 Titera, W.R., "FASB Proposes Changes in Not-For-Profit Reporting," Healthcare Financial Management, April 1993.

19 Freeman, R.J., C.D. Shoulders, Government and Nonprofit Accounting -- Theory and Practice, fourth edition, 1993, Prentice Hall, Chapter 17.

20 Statement of Financial Accounting Standards No. 116: Accounting for Contributions Received and Contributions Made, Financial Accounting Series, Financial Accounting Standards Board, June 1993.

21 Titera, April 1993.

22 For example, GAAP does not specify the degree of aggregation and order of presentation of items in the balance sheet, the statement of activities, or the statement of cash flow. Telephone conversation with Karen Burke, FASB, April 1994. 
In general, nonprofit hospitals (or healthcare systems) must submit their audited financial statements to banks loaning them funds, and to bond trustees. Moreover, bond insurance companies (such as AMBAC Investors Corporation (AMBAC), and the Municipal Bond Investors Assurance Corporation (MBIA)) typically require at least five years of audited financial statements for review before they will consider insuring a hospital's debt. Hospitals must also file an "official statement" with the Securities and Exchange Commission if they issue tax-exempt bonds. ${ }^{23}$ (It is uncertain whether these "official statements" include audited financial data.) Based on this information, it would be reasonable for a self-guarantee test to require hospitals to submit their audited financial statements in support of the test. It may be relatively difficult in some cases, however, for NRC to obtain a hospital's financial statements from a third-party source.

\subsection{DATA ON HOSPITALS THAT ARE NRC MATERIALS LICENSEES}

Exhibit 3-1 provides data on hospitals that the NRC License Tracking System (LTS) indicates must provide financial assurance. The exhibit was prepared by identifying hospitals in the LTS prepared by NRC as of October $1996 .^{24}$ For each of these hospital licensees classified as nonprofit in HCIA's 1995 Profiles of U.S. Hospitals, data on operating revenue (in millions of dollars) and Standard \& Poor's (S\&P) bond ratings were obtained from the HCIA publication. ${ }^{25}$ In addition, for each of the three financial characteristics described in Section 3.3 -- liquidity, profitability, and leverage -- a "P" designating "Pass" or a "F" designating "Fail" is included. Hospitals were considered to pass these tests if they were in the upper five deciles, and to fail if they were in the lower five (see Section 3.3). In a few instances where the S\&P bond rating was known to have changed, an updated rating is reported in the exhibit. Moody's bond ratings were obtained directly from Moody's Quarterly List of Health Care Revenue Bond Ratings, current as of July 16, 1996. All ratings are for uninsured bonds.

\subsection{EVALUATION OF ALTERNATIVE THRESHOLDS}

Using the data presented in Exhibit 3-1, thresholds were analyzed for the bond rating criterion, the financial characteristics criterion, and the financial size criterion to assess the potential availability of a financial test for nonprofit hospitals:

- The bond rating criterion tested requires hospitals to have a bond rating of "A" or better from S\&P or Moody's. Of the 26 nonprofit hospitals that are known to be NRC materials licensees, 11 hospitals ( 42 percent) pass this criterion at the stated threshold. If the criterion is modified to allow ratings on insured bonds, no additional hospitals pass the criterion.

23 Clements, B., "How to Read a Hospital's Financial Health," American Medical News, April 27, 1992.

${ }^{24}$ We did not include Mansfield General Hospital in Mansfield, Ohio, because we were unable to determine if it was a non-profit institution. HCIA does not provide information on the Washington University Medical School. We have therefore included it in the exhibit without any financial data.

${ }^{25}$ Operating revenue includes patient revenue and other operating revenue (e.g., revenues from parking and cafeteria operations), but excludes revenue from non-operating sources (e.g., investment income, charitable donations). Decile rankings for liquidity, profitability, and leverage were described in Section 3.3. The data are the most current available from HCIA. 
Exhibit 3-1

Financial Profile of

NRC Nonprofit Hospital Materials Licensees

\begin{tabular}{|c|c|c|c|c|c|c|c|c|c|}
\hline l & yo & $5+10$ & Q & 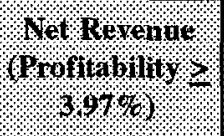 & 16, & (1) & renownot & 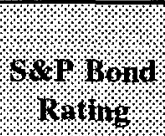 & 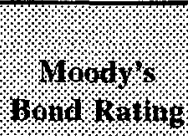 \\
\hline Georgetown University Medical Center & Washington & DC & $\mathbf{N}$ & $\mathrm{F}$ & $\mathbf{P}$ & $\mathrm{F}$ & 232.9 & - & - \\
\hline Indiana University Medical Center & Indianapolis & IN & $\mathbf{G}$ & $\mathbf{P}$ & $\mathbf{P}$ & $\mathbf{P}$ & 328.7 & $A+$ & A1 \\
\hline Beth Israel Hospital* & Boston & MA & $\mathbf{N}$ & $P$ & $\mathbf{F}$ & $\mathrm{F}$ & 398.7 & A & Al \\
\hline Boston University Medical Center & Boston & MA & $\mathbf{N}$ & F & $\mathrm{F}$ & $\mathbf{F}$ & 179.1 & - & - \\
\hline Brigham \& Women's Hospital & Boston & MA & $\mathbf{N}$ & F & $\mathbf{F}$ & $\mathbf{P}$ & 501.1 & At & A1 \\
\hline Children's Hospital -- Boston & Boston & MA & $\mathbf{N}$ & $\mathrm{F}$ & $\mathbf{F}$ & $\mathrm{P}$ & 273.1 & AA & $\mathrm{Aa}$ \\
\hline Dana-Farber Cancer Institute* & Boston & MA & $\mathbf{N}$ & $\mathrm{P}$ & $\mathrm{F}$ & $\mathrm{F}$ & 162.8 & A & A1 \\
\hline Massachusetts General Hospital & Boston & MA & $\mathrm{N}$ & F & $\mathbf{F}$ & $\mathbf{P}$ & 777.3 & A- & - \\
\hline New England Medical Center* & Boston & MA & $\mathbf{N}$ & F & $\mathbf{F}$ & $\mathrm{F}$ & 306.5 & - & - \\
\hline Harper Hospital & Detroit & MI & $\mathbf{N}$ & $\mathrm{F}$ & $\mathbf{F}$ & $\mathrm{F}$ & 308.8 & A. & - \\
\hline Henry Ford Hospital* & Detroit & MI & $\mathbf{N}$ & $\mathrm{F}$ & $F$ & $\mathrm{~F}$ & 707.3 & AA & $\mathrm{Aa}$ \\
\hline Hennepin County Medical Center & Minneapolis & $\mathrm{MN}$ & $\mathrm{G}$ & $P$ & $\mathbf{P}$ & $\mathbf{F}$ & 299.2 & - & - \\
\hline Harry S. Truman Memorial & Kansas City & MO & $\mathbf{N}$ & $\mathbf{P}$ & $\mathbf{P}$ & $\mathrm{F}$ & 121.7 & - & - \\
\hline Washington University Medical School & St. Louis & MO & - & - & - & - & - & - & - \\
\hline Helene Fuld Medical Center & Trenton & NJ & $\mathbf{N}$ & F & $\mathbf{F}$ & $\mathrm{F}$ & 105.6 & A & - \\
\hline New Jersey Univ. of Medicine \& Dentistry & Newark & NJ & G & $\mathbf{P}$ & $\mathbf{P}$ & $\mathbf{F}$ & 367.5 & - & $=$ \\
\hline
\end{tabular}


Exhibit 3-1 (continued)

Financial Profile of

NRC Nonprofit Hospital Materials Licensees

\begin{tabular}{|c|c|c|c|c|c|c|c|c|c|}
\hline Mospital & $(1 \%)$ & Strite & Ornerstipts: & 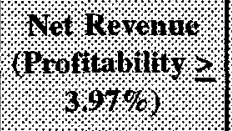 & 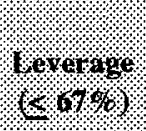 & 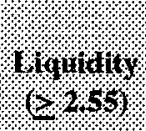 & 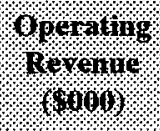 & 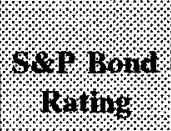 & (1) \\
\hline Medical College of Ohio & Toledo & $\mathrm{OH}$ & G & $\mathbf{P}$ & $\mathbf{P}$ & $P$ & 146.9 & - & - \\
\hline MetroHealth Medical Center & Cleveland & $\mathrm{OH}$ & G & $\mathbf{F}$ & $\mathbf{F}$ & $\mathbf{P}$ & 323.9 & - & - \\
\hline St. Luke's Medical Center & Cleveland & $\mathrm{OH}$ & $\mathrm{N}$ & $\mathbf{F}$ & $\mathbf{P}$ & $\mathrm{F}$ & 92.1 & - & A1 \\
\hline Allegheny General Hospital & Pittsburgh & PA & $\mathrm{N}$ & F & F & $P$ & 398.3 & At & A1 \\
\hline Fox Chase Cancer Center & Philadelphia & PA & $\mathrm{N}$ & F & $\mathbf{P}$ & F & 60.8 & - & - \\
\hline Geisinger Medical Center & Danville & PA & $\mathrm{N}$ & $\mathbf{F}$ & F & $\mathrm{F}$ & 239.5 & AA & $\mathrm{Aa}$ \\
\hline Milton S. Hershey Medical Center & Hershey & PA & $\mathrm{N}$ & F & - & $\mathrm{P}$ & 237.9 & - & - \\
\hline
\end{tabular}

* $\quad$ More than one license

** Ownership is defined as either not-for-profit $(\mathrm{N})$, or government $(\mathrm{G})$ 
- $\quad$ The financial characteristics criterion tested requires a hospital to rank in the top 50 percent of all U.S. hospitals in each of three financial characteristics:

- $\quad$ Liquidity: 10 of NRC's nonprofit hospital licensees (38 percent) meet the liquidity standard.

- $\quad$ Net Revenue/Profitability: 7 of NRC's nonprofit hospital licensees (27 percent) meet the net revenue/profitability measure.

- $\quad$ Leverage: 9 of NRC's nonprofit hospital licensees (35 percent) satisfy the standard for leverage.

The number of hospital licensees with scores above the median on all three of these measures is 2 out of 26 ( 8 percent). The financial characteristics criterion are more stringent than the bond rating criterion ( 8 percent of licensees pass compared to 42 percent). However, the bond rating criterion is based a more in-depth analysis. ${ }^{26}$

- $\quad$ The financial size criterion tested requires that hospitals have operating revenues of at least a certain amount relative to their assured decommissioning costs. Several alternative options for this criterion were evaluated, based on alternative decommissioning cost estimates of $\$ 372,000$ and $\$ 750,000$ per hospital, ${ }^{27}$ and assuming that the portion of operating revenue that can be allocated to pay for decommissioning equals, alternatively, one percent $(0.01)$, one-half of one percent $(0.005)$, or one-tenth of one percent $(0.001)$. For example, assuming a $\$ 750,000$ cost estimate and a one percent allocation of revenues, the implied size criterion would be $\$ 75$ million. ${ }^{28}$ Exhibit 3-2 provides the results for this alternative.

Exhibit 3-3 combines each of the three criteria (using a one percent threshold for the financial size criterion) to estimate the overall availability of tests involving a bond rating alternative and a non-bond rating alternative, with and without a size criterion, to NRC nonprofit hospital licensees.

\footnotetext{
${ }^{26}$ Rating agencies consider several additional factors, including patient mix, competitive position, sizes of market, and quality of staff.

$27 \$ 372,000$ represents the average amount assured in the non-standard decommissioning funding plans and certifications of financial assurance submitted by nonprofit hospitals to NRC and reviewed by ICF in the past five years. $\$ 750,000$ represents both the highest certification amount specified in NRC's decommissioning financial assurance regulations, and the highest amount reported by nonprofit hospitals in a sample of submissions referred to NRC Headquarters by the NRC Regional Offices.

28 It is worth noting that the financial size criterion is based on a licensee's actual decommissioning cost estimate or certification amount. Therefore, if a particular hospital had estimated decommissioning costs of $\$ 27,000$, and if NRC selected the one percent allocation factor, then the implied size threshold for this particular hospital would be $\$ 2.7$ million in operating revenues (i.e., $\$ 27,000 / 0.01$ ).
} 


\section{Exhibit 3-2}

Number and Percent of NRC Nonprofit Hospital Licensees ( $\mathbf{N}=26)$ Able to Pass the Financial Size Criterion at Alternative Thresholds

\begin{tabular}{||c|c|c||}
\hline \multirow{3}{*}{$\begin{array}{c}\text { Percent of Operating Revenue to } \\
\text { be Allocated to Pay for } \\
\text { Decommissioning Costs }\end{array}$} & \multicolumn{2}{|c|}{$\begin{array}{c}\text { Number and Percent Able to Pass Size Criterion (and Implied Size } \\
\text { Threshold) }\end{array}$} \\
\cline { 2 - 3 } & $\begin{array}{c}\text { Assuming a Cost Estimate of } \\
\$ 372,000\end{array}$ & $\begin{array}{c}\text { Assuming a Cost Estimate of } \\
\$ 750,000\end{array}$ \\
\hline \multirow{3}{*}{1 percent $(0.01)$} & $25(96 \%)$ & $24(92 \%)$ \\
& $(\$ 37.2 \mathrm{M})$ & $(\$ 75 \mathrm{M})$ \\
One-half of one percent $(0.005)$ & $24(92 \%)$ & $19(73 \%)$ \\
& $(\$ 74.4 \mathrm{M})$ & $(\$ 150 \mathrm{M})$ \\
One-tenth of one percent $(0.001)$ & $5(19 \%)$ & $1(4 \%)$ \\
& $(\$ 372 \mathrm{M})$ & $(\$ 750 \mathrm{M})$ \\
\hline
\end{tabular}

Exhibit 3-3

Number and Percent of NRC Nonprofit Hospital Licensees $(\mathbf{N}=\mathbf{2 6})$

Able to Pass the Bond Rating Alternative and Non-Bond Rating Alternative, Assuming a One Percent Threshold for the Financial Size Criterion

\begin{tabular}{|c|c|c|c|}
\hline \multirow[b]{2}{*}{ Test Alternative } & \multirow[b]{2}{*}{$\begin{array}{l}\text { Number and Percent Able to } \\
\text { Pass Without Size Criterion }\end{array}$} & \multicolumn{2}{|c|}{$\begin{array}{l}\text { Number and Percent Able to Pass } \\
\text { With Size Criterion }\end{array}$} \\
\hline & & 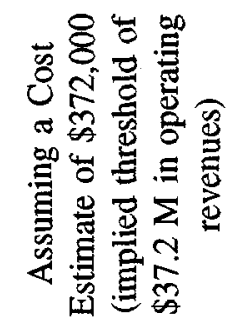 & 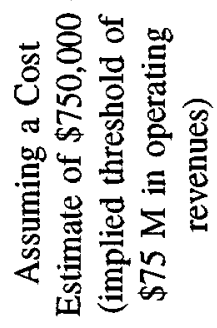 \\
\hline Bond Rating Alternative & $11(42 \%)$ & $11(42 \%)$ & $11(42 \%)$ \\
\hline Non-Bond Rating Alternative & $2(8 \%)$ & $2(8 \%)$ & $2(8 \%)$ \\
\hline
\end{tabular}

As Exhibit 3-3 demonstrates; a size criterion implying an ability to reallocate about 1 percent of operating revenue to decommissioning does not add significant stringency to test criteria based on an $\mathrm{A}$ or better bond rating or on strict financial ratio requirements. Exhibits 3-4 and 3-5 demonstrate the impact of progressively higher size criteria, which do significantly increase the stringency of both bond rating and non-bond rating tests. 


\section{Exhibit 3-4}

Number and Percent of NRC Nonprofit Hospital Licensees ( $N=26$ )

Able to Pass the Bond Rating Alternative and Non-Bond

Rating Alternative, Assuming a One-Half of One Percent

Threshold for the Financial Size Criterion

\begin{tabular}{|c|c|c||}
\hline \multirow{2}{*}{ Test Alternative } & \multicolumn{2}{|c|}{ Number and Percent Able to Pass } \\
\cline { 2 - 3 } & $\begin{array}{c}\text { Assuming a Cost Estimate of } \\
\$ 372,000 \text { (implied threshold of } \\
\$ 74.4 \mathrm{M} \text { in operating revenues) }\end{array}$ & $\begin{array}{c}\text { Assuming a Cost Estimate of } \\
\$ 750,000 \text { (implied threshold of } \\
\$ 150 \mathrm{M} \text { in operating revenues) }\end{array}$ \\
\hline Bond Rating Alternative & $11(42 \%)$ & $9(35 \%)$ \\
Non-Bond Rating Alternative & $2(8 \%)$ & $1(4 \%)$ \\
\hline
\end{tabular}

Exhibit 3-5

Number and Percent of NRC Nonprofit Hospital Licensees ( $N=26)$

Able to Pass the Bond Rating Alternative and Non-Bond

Rating Alternative, Assuming a One-Tenth of One Percent

Threshold for the Financial Size Criterion

\begin{tabular}{||l|c|c|}
\hline \multirow{2}{*}{ Test Alternative } & \multicolumn{2}{|c|}{ Number and Percent Able to Pass } \\
\cline { 2 - 3 } & $\begin{array}{c}\text { Assuming a Cost Estimate of } \\
\$ 372,000 \text { (implied threshold of } \\
\$ 372 \mathrm{M} \text { in operating revenues) }\end{array}$ & $\begin{array}{c}\text { Assuming a Cost Estimate of } \\
\$ 750,000 \text { (implied threshold of } \\
\$ 750 \mathrm{M} \text { in operating revenues) }\end{array}$ \\
\hline Bond Rating Alternative & $4(15 \%)$ & $0(0 \%)$ \\
Non-Bond Rating Alternative & $0(0 \%)$ & $0(0 \%)$ \\
\hline
\end{tabular}

\subsection{SUMMARY}

Exhibit 3-6 presents a comparison of the test alternatives, showing the number of hospital licensees that potentially could pass different formulations of the two test alternatives, at different levels of stringency. 
Exhibit 3-6

Comparison of Alternative Self-Guarantee Tests for Hospitals

\begin{tabular}{||l|l|c|}
\hline \multicolumn{2}{|c|}{ Test Alternatives } & Licensees Passing $^{\mathbf{b}}$ \\
\hline Low & Alternative 1: Size Criterion $(\$ 150 \mathrm{M}$ in operating revenue $)$ & 19 \\
\hline Moderate & Alternative 2: "A" Bond Rating & 11 \\
& Alternative 3: Financial Characteristics ${ }^{\mathrm{a}}$ & 2 \\
\hline High & Alternative 4: "A" Bond Rating + Size Criterion $(\$ 150 \mathrm{M})$ & 9 \\
& Alternative 5: Financial Characteristics + Size Criterion $(\$ 150 \mathrm{M})$ & 1 \\
\hline
\end{tabular}

a The financial characteristics criterion requires hospitals to rank above the U.S. median for each of three financial characteristics: liquidity, net revenue (or "profitability"), and leverage. (Liquidity is measured as current assets divided by current liabilities. Profitability is measured as the difference between total revenue and total expense, divided by total revenue. Leverage is measured as long-term debt to net fixed assets.)

b Numbers of passing licensees assume that all nonprofit hospitals face decommissioning costs of $\$ 750,000$. The actual number of passing licensees will vary to the extent that individual hospitals face higher or lower decommissioning costs. 


\section{ANALYSIS OF ALTERNATIVE FINANCIAL ASSURANCE CRITERIA FOR SELF-GUARANTEE BY FIRMS THAT DO NOT ISSUE BONDS}

This section examines self-guarantee financial tests that could be allowed as financial assurance mechanisms for NRC licensees that are for-profit firms that have not issued bonds rated by S\&P or Moody's. ${ }^{1}$ In particular, the analysis reviews possible alternatives for a self-guarantee financial test mechanism for non-rated firms that entails approximately the same degree of assurance risk as the criteria for self-guarantee promulgated in the final rule of December 29,1993 , which includes a bond-rating requirement and thus is available only to firms with bond ratings.

The analysis is presented below in five subsections.

- Section 4.1 summarizes the key findings from the previous analysis of assurance provided by current financial assurance mechanisms for NRC corporate licensees and by self-guarantee options that include bond-rating requirements;

- Section 4.2 describes the data used in our current analysis to identify financial test mechanisms that entail approximately the same degree of assurance risk as the current self-guarantee requirements;

- Section 4.3 describes the methodology used in our analysis;

- Section 4.4 presents our analytical findings; and

- $\quad$ Section 4.5 presents our summary and conclusions.

\footnotetext{
${ }^{1}$ Such firms might be able to qualify to use the bond rating alternative by obtaining a so-called "indicative" bond rating. Such ratings are provided by both Moody's and S\&P. Moody's explains indicative ratings in its fee materials as follows:
}

Issuers contemplating the issuance of debt at some future date are offered an indicative rating on a prospective issue. The rating is indicated on a confidential basis, subject to certain limitations in the event of debt issuance by the applicant in any of the capital markets. The indicative rating is subject to revision or withdrawal at any time, without notice, if any information (or lack of information) warrants such action, in the sole opinion of Moody's.

However, such ratings are relatively expensive. Moody's advised that in 1995-96 the firm charges $\$ 45,000$ to provide indicative ratings. S\&P advised that it charges a maximum of $\$ 90,000$, although most indicative ratings cost between $\$ 25,000$ and $\$ 40,000$. Therefore, alternative forms of financial assurance would be likely to be more attractive to non-bond issuing licensees. 


\subsection{KEY FINDINGS FROM PREVIOUS ANALYSIS OF ASSURANCE RISK}

In the analysis of financial assurance and self-guarantee options performed in $1992-1993,{ }^{2}$ the "assurance risk" of alternative financial assurance mechanisms was compared in terms of the percentage of financial assurance obligations that licensees would fail to honor, on average, in any given year. This analysis defined the assurance risk of a licensee failing to honor financial assurance obligations as the risk that the licensee would enter bankruptcy proceedings and/or default on other legal obligations.

The baseline failure rate of firms reflects their size (measured as net worth) without consideration of any additional financial assurance criteria. As might be expected, the baseline failure rate varies inversely with size, with smaller firms failing at a higher rate than larger firms. The assurance risk of a self-guarantee without any financial test will reflect the baseline failure rate, because it will depend on firm size alone. ${ }^{3}$ analysis.

Exhibit 4-1 presents the estimated baseline annual failure rates developed in ICF's previous

\section{Exhibit 4-1}

\section{Estimated Baseline Annual Firm Failure Rates}

\begin{tabular}{|cc|}
\hline $\begin{array}{c}\text { Net Worth } \\
(\$ \mathrm{MM})\end{array}$ & Failure Rate \\
\hline & \\
$0-10$ & $1.53 \%$ \\
$10-20$ & $1.24 \%$ \\
$20-100$ & $1.02 \%$ \\
$100-400$ & $0.81 \%$ \\
$400-1000$ & $0.55 \%$ \\
$>1$ billion & $0.14 \%$ \\
\hline
\end{tabular}

The assurance risk of a financial assurance mechanism with a third-party provider, such as a letter of credit, will depend on both the risk of failure by the firm and the risk of failure by the provider. It is the product of the two failure rates. Thus, for example, the estimated assurance risk of

\footnotetext{
${ }^{2}$ Analysis of Assurance Provided by Current and Proposed Financial Assurance Mechanisms, ICF Incorporated, November 1993.

3 A number of states allow firms to use self-guarantees to demonstrate coverage for workers' compensation costs, and the opportunity to self-guarantee (usually described as self-insurance) may be restricted to firms exceeding a certain size. However, most states require some other proof of financial responsibility before selfinsurance is allowed. In addition, firms may be required to provide a security, indemnity, or bond, or to become members of a self-insurance guaranty association. Therefore, the workers' compensation system of financial assurance does not provide any good models for self-guarantee tests for firms that do not issue bonds.
}

${ }^{4}$ Analysis of Assurance Provided by Current and Proposed Financial Assurance Mechanisms, November 1993, p. 26. 
standby letters of credit issued by FDIC insured banks from 1984 to 1990 ranged from approximately $0.017 \%$ to $0.001 \%$, reflecting both the baseline failure rates of the firms obtaining the letters of credit and the failure rate for banks providing the letters of credit (the third-party providers).

Financial assurance mechanisms that do not depend on a third-party provider, but instead use a screening device, such as a financial test, must if possible be evaluated in terms of the "misprediction rate" of the screening device to ascertain their assurance risk. The assurance risk of such mechanisms may reflect both the percentage of firms likely to enter bankruptcy in any given year (i.e., the firm failure rate) and the "misprediction rate" of the financial test (i.e., the percentage of bankrupt firms that could have passed the financial test in any one of the three years prior to the year of bankruptcy), ${ }^{5}$ or the screening device may measure both the likelihood of bankruptcy and the misprediction rate simultaneously. The distinction between these two types of screening devices is essentially between those that include and those that do not include a bond-rating component.

If firms must pass a financial test that does not include a bond-rating component in order to use a financial assurance mechanism, the assurance risk of the mechanism can be calculated by multiplying the firm failure rate for firms of the appropriate size times the percentage of bankrupt firms that are expected to pass the financial test in the years just prior to failure. Multiplying the annual firm failure rate times the misprediction rate for a financial test indicates the fraction of firms that are likely to enter bankruptcy each year after having satisfied the requirements of the financial test in one of the three years prior to bankruptcy.

In contrast, a financial test that includes a bond rating component effectively incorporates both the firm failure rate and the misprediction rate in the default rate for bonds. For example, the assurance risk associated with the " $\mathrm{A}$ " or better bond rating self-guarantee reflects the 0.13 percent average annual risk of default for bonds rated A or better. ${ }^{6}$ Since bond default generally indicates bankruptcy, the 0.13 percent default rate simultaneously measures both the bond rating misprediction rate and the firm failure rate for firms with that rating.

\subsection{DATA}

The analysis of alternative financial assurance criteria for self-guarantee by firms that do not issue bonds is based on data of three kinds:

Database of financial data for NRC materials licensees;

5 In previous analyses of financial test alternatives, the "misprediction rate" of a financial test has been defined as the percentage of bankrupt firms that could have passed the financial test during any of the three years prior to the year of bankruptcy. A firm that passed the financial test three years prior to bankruptcy would not produce financial reports for that fiscal year until after the books were closed at the end of the year, which would be less than two years prior to the year of bankruptcy. A financial test submission based on that most recent financial report could be made any time over the course of the next year. Therefore, it could be less than one year prior to bankruptcy when these financial results were used as the basis for financial assurance.

Therefore, a firm should fail a financial test in all three years prior to bankruptcy in order to ensure that there is sufficient time for the firm to obtain an alternative financial assurance mechanism prior to year of bankruptcy.

6 Corporate Bond Defaults and Default Rates, 1970-1990, Moody's Special Report, January 1991, Table 4, p. 32. For a discussion of this estimate, see Analysis of Assurance Provided by Current and Proposed Financial Assurance Mechanisms, November 1993, pp. 57- 59. 

Database of financial data for bankrupt firms; and

(3) Database of financial data for firms that are materials licensees that do not issue bonds.

Financial Database: The database of financial data for NRC materials licensees was developed in 1992 to support the initial analysis of self-guarantee alternatives for materials licensees. In order to maintain consistency with that analysis, and to limit additional costs, the database was not updated for the current analysis. Therefore, this analysis is based on financial data for NRC licensees that is two to four years old. Furthermore, the database of NRC licensees does not include data on depreciation, depletion, and amortization, which results in an underestimate for cash-flow generated by licensees (i.e., estimated cash-flow reflects cash-flow from net income only).

The financial database also includes information on the bond ratings of all licensees who were identified in 1992 as having a bond rating. In some cases, these ratings have been reviewed subsequently.

Bankrupt Firm Database: ICF has developed a bankrupt firm sample that can be used to estimate the misprediction rate for particular financial tests. This sample consists of firms which had net worth of at least $\$ 10$ million at some time prior to firm failure. Firms with less than $\$ 10$ million in net worth were excluded from the sample because at the time the data were collected the financial tests considered by EPA (and NRC) had always included a minimum net worth requirement of at least $\$ 10$ million. The bankrupt firm sample also includes only firms for which financial data was available for three complete years prior to the year of bankruptcy.

The bankrupt firm sample includes only 34 firms. One reason for this relatively small sample size is the fact that firm failure is relatively uncommon for firms with more than $\$ 10$ million in net worth (as indicated by firm failure rates in Exhibit 4-1). Also, three years of financial data were not always available for firms that had entered bankruptcy.

Three firms should be excluded from the analysis because of the circumstances of their bankruptcy. Texaco was a strategic bankruptcy rather than a true financial bankruptcy (Texaco entered Chapter 11 in response to a legal action, and later satisfied all of their financial obligations after emerging from Chapter 11). The Penn Central and the Erie Lackawanna Railway Company failures occurred more than 20 years ago (1970 and 1972). These exclusions reduce the bankrupt firm sample to just 31 firms that failed between 1975 and 1988. Although a sample size of more than 30 is generally considered statistically significant, the limited size of the bankrupt firm sample does reduce the precision of any assurance risk estimate for financial test alternatives. For example, the limited size of the bankrupt firm sample does not permit a statistically significant estimate of misprediction rates for individual net worth categories. Therefore, the misprediction rate estimates developed from the bankrupt firm sample reflect average misprediction rates for all firms with net worth greater than $\$ 10$ million.

Database of Firms that do not Issue Bonds: Data pertaining to the 36 firms that are NRC materials licensees and have not issued bonds were isolated to allow separate investigation of their financial characteristics. ${ }^{7}$

${ }^{7}$ Only firms that had not issued rated bonds and that did not appear to have a corporate parent were included. Firms with corporate parents were assumed to be eligible to use NRC's parent company guarantee. 


\subsection{METHODOLOGY USED IN ANALYSIS OF SELF-GUARANTEE FINANCIAL TESTS}

The financial criteria used in the NRC parent company guarantee were used as a starting point to develop alternative criteria for the self-guarantee test for firms that do not issue bonds. This approach was chosen for a number of reasons. First, it helps to maintain consistency with existing NRC rules and with the previous analyses of self-guarantee alternatives. Second, it provides access to a substantial body of research that has already been carried out on financial test alternatives. The NRC financial test supporting parent guarantees has equivalent criteria to the current EPA financial test, which has recently been reevaluated by EPA. The results of that reevaluation were available for this analysis to identify potential components of a self-guarantee test. ${ }^{8}$ Finally, using the parent guarantee criteria as a starting point was most responsive to Commissioner de Planque's comments on SECY-93-284.

Evaluation of potential revisions to financial test criteria identified two key financial ratios that are especially effective in identifying firms that ultimately enter bankruptcy. These two ratios are:

- Cash-flow divided by total liabilities (CF/TL), where cash-flow is defined as net income plus depreciation, depletion, and amortization (i.e., net income plus non-cash expenses); and

- Total liabilities divided by net worth (TL/NW), also known as the debt-toequity ratio.

In the current analysis, to identify self-guarantee financial tests that entail approximately the same assurance risk as the " $\mathrm{A}$ " or better bond rating alternative, ICF examined four different threshold requirements for these two key financial ratios, and the resulting misprediction rates for financial tests that require these different thresholds. Exhibit 4-2 describes the specific financial test alternatives that were examined:

\section{Exhibit 4-2}

Financial Test Alternatives for Self-Guarantee

\begin{tabular}{|lllll||}
\hline (1) & (CF/TL) $>0.07$ & and & (TL/NW) $<2.7$ & $\begin{array}{l}\text { (Average values for self-guaranteeing } \\
\text { bond-issuing firms) }\end{array}$ \\
$(2)$ & $(\mathrm{CF} / \mathrm{TL})>0.1$ & or & $(\mathrm{TL} / \mathrm{NW})<1.5$ & (Revised values for EPA financial test) \\
$(3)$ & $(\mathrm{CF} / \mathrm{TL})>0.1$ & and & $(\mathrm{TL} / \mathrm{NW})<1.5$ & (More stringent alternative to (2)) \\
$(4)$ & $(\mathrm{CF} / \mathrm{TL})>0.15$ & and & $(\mathrm{TL} / \mathrm{NW})<1.5$ & $\begin{array}{l}\text { (Thresholds equivalent to bond rating } \\
\text { alternative) }\end{array}$ \\
\hline
\end{tabular}

8 The analysis and revised criteria are described in 56 Federal Register 30201, July 1, 1991, proposing to amend the EPA financial test criteria for closure and post-closure care of hazardous waste management facilities (40 CFR Parts 264 and 265). The amended criteria have not yet been promulgated as a final rule. In addition, EPA is currently evaluating criteria for solid waste management facilities, and these criteria may differ from those proposed in 1991 for hazardous waste management facilities. (See Draft Background Document, Subtitle D Financial Test for Closure, Post-Closure Care, and Corrective Action (40 CFR Part 258), U.S. EPA, December 15, 1992). 
The first financial test alternative was developed by determining the average values for the two key financial ratios for firms that pass the self-guarantee test criteria adopted by NRC on December 29,1993 . Firms passing the self-guarantee test were identified from the database of NRC materials licensees and the values for the two ratios were measured. (These ratios are not a part of the selfguarantee test but were included in the database to allow tests including those criteria to be evaluated.)

The second test examined reflects new financial ratio thresholds proposed in 1991 by EPA, based on EPA's reevaluation of financial test criteria for hazardous waste management facilities. ${ }^{9}$ ' If adopted, these criteria would be available to firms to demonstrate to EPA either a parent guarantee or a self-guarantee for closure and post-closure care of hazardous waste management facilities.

The last two financial test alternatives reflect progressively more stringent variations of the second set of criteria. These alternatives demonstrate the thresholds required to achieve a test with an assurance risk equivalent to NRC's bond-rating alternative. The reasons why such stringent criteria are needed to achieve equivalency are discussed below.

Each of the alternatives also had an implicit requirement of at least $\$ 10$ million in tangible net worth, since the database included only firms that exceeded that level. This factor, however, could be considered a surrogate for the 10 times decommissioning costs requirement in the current selfguarantee test, assuming decommissioning costs average $\$ 1$ million per licensee.

Each alternative was evaluated by determining (1) whether the firms database of licensees that do not issue bonds could pass the alternative and (2) the ability of the alternative to identify firms in the bankrupt firm sample as risks three or more years in advance of bankruptcy (i.e., the misprediction rate of the alternative).

\subsection{ANALYTICAL FINDINGS}

Our analysis of each of the financial tests described above are presented in subsections 4.4 .1 through 4.4.4.

\subsubsection{Analysis of Test One: (CF/TL) $>0.07$ and $(\mathrm{TL} / \mathrm{NW})<2.7$}

The database of NRC licensees indicates that firms with an A or better bond rating have, on average, an estimated cash-flow ratio (CF/TL) of 0.07 , and a debt-to-equity ratio (TL/NW) of 2.7. The estimated cash-flow understates the actual cash-flow ratio for these firms because the database of NRC licensees does not include data on depreciation, depletion, and amortization. Therefore, the estimated average cash-flow ratio for firms with $\mathrm{A}$ or better bond ratings actually reflects only net income divided by net worth.

Using these cash flow and debt-to-equity ratios as financial ratio thresholds would result in a test with thresholds less stringent than the thresholds required by NRC's parent guarantee financial test (i.e., 0.1 for the cash-flow ratio, and 2.0 for the debt-to-equity ratio). NRC has already determined that a self-guarantee with these ratio requirements would entail assurance risk that is significantly higher than the risk associated with the $\mathrm{A}$ or better bond rating alternative. Therefore, this alternative was not evaluated further.

956 Federal Register 30201, July 1, 1991. 
The average value of key financial ratios for firms with $A$ or better bond ratings reflects the fact that the firms with bond ratings are disproportionately concentrated in very high net worth categories (i.e., net worth $>\$ 1$ billion). Key financial ratios are relatively less important in predicting firm failure for such large firms, because the baseline failure rate for such large firms is extremely low. Bond ratings also reflect a more detailed case-specific analysis of market conditions and trends affecting a particular firm. For these reasons, more stringent thresholds for key financial ratios are necessary to achieve the same low assurance risk as the A or better bond rating alternative.

\subsubsection{Analysis of Test Two: (CF/TL) $>0.1$ or $(\mathrm{TL} / \mathrm{NW})<1.5$}

The NRC's current parent guarantee financial test requires firms to satisfy two of the following three ratio requirements:

1. $(\mathrm{CF} / \mathrm{TL})>0.1$

2. $(\mathrm{TL} / \mathrm{NW})<2.0$; and

3. Current assets divided by current liabilities $>1.5$.

The NRC's current parent guarantee financial test is substantially equivalent currently to a financial test current authorized by EPA for use by its hazardous waste permittees. However, over the past four years, EPA has reevaluated that test. EPA's reevaluation of RCRA Subtitle C financial tests determined that the current ratio (current assets divided by current liabilities) is a relatively weak predictor of firm failure. Therefore, EPA's new proposed financial test requires firms to pass either the cash-flow ratio requirement or a more stringent debt-to-equity ratio requirement: ${ }^{10}$

$$
\begin{aligned}
& \text { 1. }(\mathrm{CF} / \mathrm{TL})>0.1 \text {; or } \\
& \text { 2. }(\mathrm{TL} / \mathrm{NW})<1.5
\end{aligned}
$$

EPA determined that the misprediction rate of this proposed test is lower than the misprediction rate of the current financial test. Therefore, ICF examined this test as an alternative financial test for nonbond issuing NRC licensees.

Our analysis of the bankrupt firm sample indicates that nine out of 31 firms in the bankruptcy sample could have passed both of these requirements in one of the three years prior to the year of their bankruptcy. Therefore, the misprediction rate for this self-guarantee is 29 percent $(9 / 31=0.29)$. Exhibit 4-3 shows that this misprediction rate results in an annual assurance risk greater than 0.13 percent for firms with net worth of less than $\$ 1$ billion.

Our analysis of the database of licensees that do not issue bonds indicates that this financial test (including a minimum net worth requirement of $\$ 10$ million) would be available to 25 out of 36 of these licensees that do not have bonds rated by Moody's or S\&P. (However, it is possible that other firms could also qualify, because the database of NRC licensees does not include data on depreciation, depletion, and amortization.)

${ }^{10} 56$ Federal Register 30201, July 1, 1991. 
Exhibit 4-3

Assurance Risk for Self-Guarantee Requiring

$(\mathrm{CF} / \mathrm{TL})>0.1$ or $(\mathrm{TL} / \mathrm{NW})<1.5$

\begin{tabular}{|crrr|}
\hline Net Worth (\$MM) & Failure Rate & Misprediction & Assurance Risk \\
$10-20$ & $1.24 \%$ & $29 \%$ & $0.36 \%$ \\
$20-100$ & $1.02 \%$ & $29 \%$ & $0.30 \%$ \\
$100-400$ & $0.81 \%$ & $29 \%$ & $0.23 \%$ \\
$400-1000$ & $0.55 \%$ & $29 \%$ & $0.16 \%$ \\
$>1$ billion & $0.14 \%$ & $29 \%$ & $0.04 \%$ \\
\hline
\end{tabular}

\subsubsection{Analysis of Test Three: (CF/TL) $>0.1$ and $(\mathrm{TL} / \mathrm{NW})<1.5$}

The third alternative is a financial test that requires firms to pass both the cash-flow ratio and the debt-to-equity ratio requirements of the proposed EPA test. Requiring licensees to pass both of the ratio requirements should result in a more stringent financial test, with a lower misprediction rate than EPA's proposed test.

Our analysis of the bankrupt firm sample confirms that only six out of 31 firms in the bankruptcy sample could have passed both of these requirements in one of the three years prior to the year of bankruptcy. Therefore, the misprediction rate for this self-guarantee is 19 percent $(6 / 31=0.19)$. However, Exhibit 4-4 shows that this misprediction rate still results in an annual assurance risk greater than 0.13 percent for firms with net worth less than $\$ 400$ million.

\section{Exhibit 4-4}

Assurance Risk for Self-Guarantee Requiring

$(\mathrm{CF} / \mathrm{TL})>0.1$ and $(\mathrm{TL} / \mathrm{NW})<1.5$

\begin{tabular}{|c|c|c|c|}
\hline $\begin{array}{l}\text { Net Worth } \\
\text { (\$MM) }\end{array}$ & Failure Rate & Misprediction & Assurance Risk \\
\hline $10-20$ & $1.24 \%$ & $19 \%$ & $0.24 \%$ \\
\hline $20-100$ & $1.02 \%$ & $19 \%$ & $0.19 \%$ \\
\hline $100-400$ & $0.81 \%$ & $19 \%$ & $0.15 \%$ \\
\hline $400-1000$ & $0.55 \%$ & $19 \%$ & $0.10 \%$ \\
\hline$>1$ billion & $0.14 \%$ & $19 \%$ & $0.03 \%$ \\
\hline
\end{tabular}

Our analysis of the database of licensees that do not issue bonds indicates that this financial test (including a minimum net worth requirement of $\$ 10$ million) could be passed by only four of the 36 licensees that do not have bonds rated by Moody's or S\&P. However, it is possible that other firms could also qualify, because the database of NRC licensees does not include data on depreciation, depletion, and amortization. Therefore, the number of firms passing the cash-flow ratio requirement actually reflects only firms with net income divided by total liabilities greater than 1.0. 


\subsubsection{Analysis of Test Four: (CF/TL) $>0.15$ and (TL/NW) $<1.5$}

Finally, ICF examined a financial test that combines the requirement in Test Two for the debtto-equity ratio (1.5) with a very stringent requirement for the cash flow ratio $(0.15)$ :

1. $(\mathrm{CF} / \mathrm{TL})>0.15$; and

2. $(\mathrm{TL} / \mathrm{NW})<1.5$

Our analysis of the bankrupt firm sample indicates that only three out of 31 firms in the bankruptcy sample could have passed both of these requirements in one of the three years prior to the year of bankruptcy. Therefore, the misprediction rate for this self-guarantee is only 10 percent $(3 / 31=0.10)$. Exhibit $4-5$ shows that this misprediction rate results in an annual assurance risk as low as 0.13 percent for firms with net worth greater than $\$ 10$ million.

Exhibit 4-5

Assurance Risk for Self-Guarantee Requiring

$(\mathrm{CF} / \mathrm{TL})>0.15$ and $(\mathrm{TL} / \mathrm{NW})<1.5$

\begin{tabular}{|c|c|c|c|}
\hline $\begin{array}{l}\text { Net Worth } \\
\text { (\$MM) }\end{array}$ & Failure Rate & Misprediction & Assurance Risk \\
\hline $10-20$ & $1.24 \%$ & $10 \%$ & $0.12 \%$ \\
\hline $20-100$ & $1.02 \%$ & $10 \%$ & $0.10 \%$ \\
\hline $100-400$ & $0.81 \%$ & $10 \%$ & $0.08 \%$ \\
\hline $400-1000$ & $0.55 \%$ & $10 \%$ & $0.06 \%$ \\
\hline$>1$ billion & $0.14 \%$ & $10 \%$ & $0.01 \%$ \\
\hline
\end{tabular}

Our analysis of the database of licensees that do not issue bonds indicates that this financial test (including a minimum net worth requirement of $\$ 10$ million) could be passed by only 2 of the 36 licensees that do not have bonds rated by Moody's or S\&P. (However, it is possible that other firms could also qualify, because the database of NRC licensees does not include data on depreciation, depletion, and amortization.)

\subsection{SUMMARY}

A comparison of the estimated potential pass rates and relative assurance risk of the four tests evaluated is presented in Exhibit 4-6. As the exhibit indicates, a self-guarantee test for materials licensees who have not issued bonds that achieves approximately the same level of stringency as the current self-guarantee test for firms that issue bonds is unlikely to be available to a high proportion of licensees who do not issue bonds. Such a test must be very stringent to result in an assurance risk as low as the 0.13 percent assurance risk of the $\mathrm{A}$ or better bond rating mechanism. Our analysis identified one test that achieves this objective (See Section 4.4.4):

Test Four: $(\mathrm{CF} / \mathrm{TL})>0.15$; and $(\mathrm{TL} / \mathrm{NW})<1.5$. 
Exhibit 4-6

Estimated Availability of Self-Guarantee Alternatives to NRC Materials Licensees That Do Not Issue Bonds

\begin{tabular}{|c|c|c|c|c|c|}
\hline \multirow{2}{*}{\multicolumn{2}{|c|}{ Test Alternative }} & \multicolumn{3}{|c|}{ Estimated Availability } & \multirow[b]{2}{*}{$\begin{array}{c}\text { Relative } \\
\text { Assurance Risk }\end{array}$} \\
\hline & & $\begin{array}{l}\text { Number of } \\
\text { Licensees } \\
\text { Passing }\end{array}$ & $\begin{array}{l}\text { \% Passing } \\
(\mathrm{N}=36)\end{array}$ & $\begin{array}{c}\text { Misprediction } \\
\text { Rate } \\
(\mathrm{N}=31)\end{array}$ & \\
\hline & $\begin{array}{l}(\mathrm{CF} / \mathrm{TL})^{\mathrm{a}}>0.07 \text { and } \\
(\mathrm{TL} / \mathrm{NW})^{\mathrm{b}}<2.7\end{array}$ & $>25$ & $>69 \%$ & $>29 \%$ & $\begin{array}{l}\text { Moderate to High/ } \\
\text { Equivalent to bond } \\
\text { rating below } \mathrm{A}\end{array}$ \\
\hline & $\begin{array}{l}(\mathrm{CF} / \mathrm{TL})>0.1 \text { or } \\
(\mathrm{TL} / \mathrm{NW})<1.5\end{array}$ & 25 & $69 \%$ & $29 \%$ & $\begin{array}{l}\text { Moderate/ } \\
\text { Equivalent to EPA } \\
\text { revised test for } \\
\text { self-guarantee and } \\
\text { parent guarantee }\end{array}$ \\
\hline (3) & $\begin{array}{l}(\mathrm{CF} / \mathrm{TL})>0.1 \text { and } \\
(\mathrm{TL} / \mathrm{NW})<1.5\end{array}$ & 4 & $11 \%$ & $19 \%$ & Low to Moderate \\
\hline & $\begin{array}{l}(\mathrm{CF} / \mathrm{TL})>0.15 \text { and } \\
(\mathrm{TL} / \mathrm{NW})<1.5\end{array}$ & 2 & $6 \%$ & $10 \%$ & $\begin{array}{l}\text { Low/Equivalent to } \\
\text { self-guarantee test } \\
\text { for firms issuing } \\
\text { bonds }\end{array}$ \\
\hline
\end{tabular}

a Cash Flow/Total Liabilities.

b Total Liabilities/Net Worth.

This test results in an assurance risk of less than 0.13 percent. However, it is passed by only 2 of the 36 licensees that do not have bonds rated by Moody's or S\&P.

A self-guarantee test for NRC materials licensees who do not issue bonds that achieves a moderate level of stringency and at the same time could be passed by more than a very small number of licensees is Test Two. This test results in a moderate assurance risk, but is capable of being passed by approximately 25 firms, or $69 \%$ of the NRC licensees that do not issue bonds. Test Two is currently being finally evaluated by EPA, for use as the criteria for both parent company guarantees and self-guarantees for both hazardous waste management facilities and non-hazardous waste management facilities under RCRA. EPA has apparently established an informal timetable that would lead to promulgation of the revised test by the end of 1995. If promulgated, the test would replace the test that closely resembles NRC's current financial test for parent guarantees. 


\section{REFERENCES}

AMBAC Investors Corporation, Hospital Underwriting Criteria, 1995.

Applebone, Peter, "Hurry! Hurry! Hurry! Get Your College Discounts: Competition Sets Off Price Wars in Academia," The New York Times, December 25, 1994, A1, A28.

Brown, V.H. and S.E. Weiss, "Toward Better Not-For-Profit Accounting and Reporting," Management Accounting, July 1993.

Chabotar, Kent John, "Financial Ratio Analysis Comes to Nonprofits," 60 Journal of Higher Education, March/April 1989.

Clements, B., "How to Read a Hospital's Financial Health," American Medical News, April 27, 1992.

Cleverley, W.O., "More Efficient Hospitals are Closing," Healthcare Financial Management, April 1993.

Cleverley, W.O., "Predicting Hospital Failure With the Financial Flexibility Index," Healthcare Financial Management, May 1985.

Corporate Bond Defaults and Default Rates, 1970-1990, Moody's Special Report, January 1991.

Dickmeyer, N., "Assessing the Financial Health of Institutions," Educational Record, 1979.

Financial Accounting Standards Board, Statement of Financial Accounting Standards No. 116:

Accounting for Contributions Received and Contributions Made, Financial Accounting Series, June 1993.

Financial Accounting Standards Board, Statement of Financial Accounting Standards No. 117, Financial Statements of Not-For-Profit Organizations, June 1993.

Freeman, R.J., C.D. Shoulders, Government and Nonprofit Accounting -- Theory and Practice, Prentice Hall, fourth edition, 1993.

Graham, Ellen, "The Halls of Ivy Imitate Halls of Commerce," The Wall Street Journal, October 10, 1994, pp. B1, B10.

HCIA, Inc., Profiles of U.S. Hospitals, 1995; and HCIA, Inc., Profiles of U.S. Hospitals, 1996.

Harr, D.J. and R.H. Frank, "Coming: New Nonprofit Financial Statements (Part 1)," Nonprofit World, May/June 1994.

ICF Incorporated, Analysis of Assurance Provided by Current and Proposed Financial Assurance Mechanisms, November 1993.

Jenny, H. and J. Minter, "Updating Financial Ratios," NACUBO Business Officer, 1993. 
KPMG Peat Marwick, Ratio Analysis in Higher Education, Second Edition, 1991.

Lumsdon, K., "Bond Update: Slowing But Continued Deterioration," Healthcare Financial Management, September 1990.

Moody's Rating Process, 1989.

Municipal Bond Investors Assurance Corporation, Healthcare Underwriting Criteria, 1995.

1993 NACUBO Endowment Study, prepared by Cambridge Associates, Inc., 1994; 1994 NACUBO Endowment Study, prepared by Cambridge Associates, Inc., 1995; and 1995 NACUBO Endowment Study, prepared by Cambridge Associates, Inc., 1996.

National Association of College and University Business Officers (NACUBO), Financial SelfAssessment: A Workbook for Colleges, 1980.

Nemes, J., "Hospitals Signaling Distress," Modern Healthcare, March 4, 1991

Ostrom, John, Accounting for Contributions: Understanding the Requirements of FASB Statement No 116, NACUBO, 1996.

"S\&P: Anatomy of Four Recent Hospital Bond Defaults," Hospitals, August 5, 1990

Sherman, B., "How Investors Evaluate the Creditworthiness of Hospitals," Healthcare Financial Management, March 1990.

Standard \& Poor's Municipal Finance Criteria, 1994.

Standard \& Poor's and The Wall Street Journal: "Credit Comments: Ratios Testify to Higher Education Woes," Standard and Poor's Creditweek Municipal, October 25, 1993.

Stecklow, Steve, "A Big University Shapes Up by Downsizing," The Wall Street Journal, October 10, 1994, B1, B10

Taylor, B., "Monitoring the Financial Condition of Colleges and Universities, AAHE Bulletin, 1984.

Titera, W.R., "FASB Proposes Changes in Not-For-Profit Reporting," Healthcare Financial Management, April 1993.

"U.S. Universities at an Economic Crossroads," The Wall Street Journal, October 10, 1994, B1.

The Wall Street Journal, "Rating College Debt Calls for Refresher Course as Standards Change," May 25, 1995, A1. 
(See instructions on the reverse)

2. TITLE AND SUBTITLE

NUREG/CR-6514

Analysis of Potential Self-Guarantee Tests for Demonstrating Financial Assurance by Non-Profit Colleges, Universities, and Hospitals and by Business Firms That Do Not Issue Bonds

P. Bailey, C. Dean, J. Collier, V. Dasappa, W. Goldberg

3. DATE REPORT PUBLISHED

MONTH

June

4. FIN OR GRANT NUMBER W6295

6. TYPE OF REPORT

Technical

(Assigned by NRC, Add Vol., Supp., Rev., and Addendum Numbers, if any.) 1997

7. PERIOD COVERED (nalusive Dates)

1996-1997

8. PERFORMING ORGANIZATION - NAME AND ADDRESS (I NRC, provide Division, Office or Region, U.S. Nuclear Regulation Commission, and mailing address; if contractor, provide name and mailing address.)

ICF, Inc.

9300 Lee Highway

Fairfax, VA 22301-1207

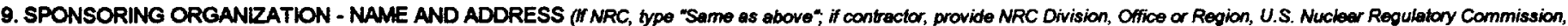
and moiling addrass.)

Division of Regulatory Applications

Office of Nuclear Regulatory Research

U.S. Nuclear Regulatory Commission

Washington, DC 20555-0001

10. SUPPLEMENTARY NOTES

C. Prichard, NRC Project Manager

11. ABSTRACT (200 monds or kass)

This reports describes potential financial tests which could be used by NRC as a basis for allowing certain financially strong non-profit licensees, and also non-bond issuing licensees, to use self-guarantee as a mechanism for meeting NRC financial assurance requirements. The analysis focuses on three categories of licensees; colleges or universities, hospitals, and commercial firms that do not issue bonds. The report assesses the financial assurance risk of various financial tests, and also estimates the number of licensees which could qualify for self-guarantee under different financial test alternatives.

12. KEY WORDS/DESCRIPTORS (List words or phrases that will assist reseerchers in locating the report.)

\begin{tabular}{|c|}
\hline $\begin{array}{l}\text { 13. AVAILABILITY STATEMENT } \\
\text { unlimited }\end{array}$ \\
\hline 14. SECURITY CLASSIFICATION \\
\hline (This Page) \\
\hline unclassified \\
\hline $\begin{array}{l}\text { (This Report) } \\
\quad \text { unclassified }\end{array}$ \\
\hline 15. NUMBER OF PAGES \\
\hline 16. PRICE \\
\hline
\end{tabular}

Financial assurance

Decommissioning 